\title{
Article
}

\section{TNF $\alpha$-Induced LDL Cholesterol Accumulation Involve Elevated LDLR Cell Surface Levels and SR-B1 Downregulation in Human Arterial Endothelial Cells}

\author{
Emmanuel Ugochukwu Okoro
}

check for updates

Citation: Okoro, E.U. TNF $\alpha$-Induced LDL Cholesterol Accumulation Involve Elevated LDLR Cell Surface Levels and SR-B1 Downregulation in Human Arterial Endothelial Cells. Int J. Mol. Sci. 2021, 22, 6236. https:// doi.org/10.3390/ijms22126236

Academic Editor: Jeffrey L. Platt

Received: 17 May 2021

Accepted: 7 June 2021

Published: 9 June 2021

Publisher's Note: MDPI stays neutral with regard to jurisdictional claims in published maps and institutional affiliations.

Copyright: (C) 2021 by the author. Licensee MDPI, Basel, Switzerland. This article is an open access article distributed under the terms and conditions of the Creative Commons Attribution (CC BY) license (https:// creativecommons.org/licenses/by/ $4.0 /)$.
Department of Microbiology, Immunology and Physiology, Meharry Medical College, Nashville, TN 37208, USA; eokoro@mmc.edu

Abstract: Excess lipid droplets are frequently observed in arterial endothelial cells at sites of advanced atherosclerotic plaques. Here, the role of tumor necrosis factor alpha $(\mathrm{TNF} \alpha)$ in modulating the low-density lipoprotein (LDL) content in confluent primary human aortic endothelial cells (pHAECs) was investigated. TNF $\alpha$ promoted an up to 2 folds increase in cellular cholesterol, which was resistant to ACAT inhibition. The cholesterol increase was associated with increased ${ }^{125}$ I-LDL surface binding. Using the non-hydrolysable label, Dil, TNF $\alpha$ could induce a massive increase in Dil-LDL by over 200 folds. The elevated intracellular Dil-LDL was blocked with excess unlabeled LDL and PCSK9, but not oxidized LDL (oxLDL), or apolipoprotein (apoE) depletion. Moreover, the TNF $\alpha$-induced increase of LDL-derived lipids was elevated through lysosome inhibition. Using specific LDLR antibody, the Dil-LDL accumulation was reduced by over $99 \%$. The effects of TNF $\alpha$ included an LDLR cell surface increase of $138 \%$, and very large increases in ICAM-1 total and surface proteins, respectively. In contrast, that of scavenger receptor B1 (SR-B1) was reduced. Additionally, LDLR antibody bound rapidly in TNF $\alpha$-treated cells by about 30 folds, inducing a migrating shift in the LDLR protein. The effect of TNF $\alpha$ on Dil-LDL accumulation was inhibited by the antioxidant tetramethythiourea (TMTU) dose-dependently, but not by inhibitors against NF- $\mathrm{B}$, stress kinases, ASK1, JNK, p38, or apoptosis caspases. Grown on Transwell inserts, TNF $\alpha$ did not enhance apical to basolateral LDL cholesterol or Dil release. It is concluded that TNF $\alpha$ promotes LDLR functions through combined increase at the cell surface and SR-B1 downregulation.

Keywords: cell surface receptor; cholesterol; endothelial cell; lipoprotein; low-density lipoprotein (LDL); tumor necrosis factor (TNF)

\section{Introduction}

$\mathrm{TNF} \alpha$ was originally described as a tumor-selective hemorrhagic factor $[1,2]$. However, it is now recognized to have multiple cell-type dependent effects $[3,4]$. Released as a $17 \mathrm{kD}$ soluble protein from a transmembrane precursor by tumor necrosis factor converting enzyme (TACE) [5-7], this cytokine mainly promotes changes that facilitate leukocyte (inflammatory) functions [3,8]. Some of its early intracellular cascade molecules include the rapid-acting transcription factor, nuclear factor kappa B (NF-kB), which induces the expression of other pro-inflammatory mediators such as interleukin 1 and 2 [9,10]. Likewise, $\mathrm{TNF} \alpha$ is capable of inducing apoptosis [11-13], possibly through c-jun N-terminal kinase (JNK) activation [14-16]. Thus, TNF $\alpha$ may clear a way for the passage of leukocytes through target epithelial cell apoptosis. In contrast, it can directly or indirectly induce the proliferation of lymphocytes, fibroblasts, and endothelial cells [12,17-20]. This ability to induce proliferation has been reported to be due to the upregulation of growth factor receptors [20,21] or growth factor release, such as vascular endothelial growth factor (VEGF) [20,22,23].

The pro-atherogenic arm of $\mathrm{TNF} \alpha$ is in part due to its ability to enhance monocyte entry into the intima through induction of adhesion molecules on arterial endothelial 
cells. In atherosclerotic lesions, macrophages [22] and smooth muscle cells [22,23] have been found to express $\mathrm{TNF} \alpha$, where it acts on overlying endothelial cells to stimulate the expression of leukocyte adhesion molecules such as E-selectin, vascular cell adhesion molecule-1 (VCAM-1), and intercellular adhesion molecule-1 (ICAM-1) [24]. Moreover, it induces expression of monocyte chemoattractant protein I (MCP-1) [25], which stimulates the gradient migration of lymphocytes and monocytes [26,27].

The serum concentration of TNF $\alpha$ rises with atherosclerotic severity [28]. Thus, it has been reported to be about 200 folds higher in the atherosclerotic lesion than in the circulating blood [29]. Moreover, age [30], vascular infection [31,32], and psychoenvironmental stress [33] are associated with elevated serum TNF $\alpha$. Although it is considered a pro-inflammatory cytokine, the effect of TNF $\alpha$ on atherogenesis is surprisingly mixed. For example, tumor necrosis factor receptor 1 (TNFR1) has been reported to be anti-atherogenic [34,35], pro-atherogenic [36-38], or neutral [39]. Likewise, TNFR2 has been reported to be pro-atherogenic [40] or neutral [35]. On one hand, it has been reported to promote advanced lesion development [36,41-43]. However, others have reported that it suppresses the early stages of the disease [43], while antibodies against TNF $\alpha$ have been shown to be atherogenic [44].

Unlike macrophages [45,46] and smooth muscle cells [45,47], confluent endothelial cells, which represent the form in which they exist in the arterial wall, are resistant to cholesterol accumulation [48]. Specifically, in the atherosclerotic lesion, macrophages and smooth muscle cells become cholesteryl ester laden cells called foam cells, in association with oxidized LDL (oxLDL) uptake via scavenger receptor A (SR-A) [49]. Macrophages naturally express large quantities of SR-A, whereas smooth muscle cells can be induced to express it [50]. However, atherosclerotic lesions also contain endothelial foam cells within an intact monolayer [51-53]. The expression of lectin-like oxidized LDL receptor 1 (LOX-1) has been reported to be inducible in endothelial cells [54]. This may contribute to endothelial foam cell formation. However, oxLDL induces endothelial apoptosis [55,56]. Thus, the knowledge that atherosclerotic endothelial foam can exist without apparent damage [53] raises the question as to whether the concentration of oxLDL is sufficient to induce endothelial foam cell formation in vivo.

In this report, the effect of TNF $\alpha$ on the pro-atherogenic lipoprotein, LDL $[57,58]$ is investigated. Evidence is presented that native LDL uptake alteration in pHAECs may contribute to the atherogenic nature of TNF $\alpha$ and LDL. It is shown that TNF $\alpha$ increases pHAEC cholesterol and lipid accumulation by enhancing LDL receptor (LDLR) functions.

\section{Results}

\subsection{TNF $\alpha$ Enhances Cholesterol Accumulation and LDL Binding to $p H A E C S$}

Atherosclerotic lesion is characterized by release of inflammatory cytokines, among which is TNF $\alpha$. Prior to the initiation of experiments, the pHAECs obtained from ATCC were routinely verified through cellular morphological criteria and VWF expression [59]. As shown in Figure 1A, the pHAECs expressed VWF. The characteristic "cobble stone" appearance of endothelial cells can be seen at the level of confluency shown in Figure 1B. Prolonged maintenance at confluence increases the cell number, while the individual cell size is decreased (Figure 1C). The in vivo level of arterial endothelial confluency is closer to that seen in Figure 1C [53]. To evaluate the effect of TNF $\alpha$ on pHAECs cholesterol content, confluent pHAECs were treated with or without TNF $\alpha$ and the cellular cholesterol content was measured. As is shown in Figure 1D, TNF $\alpha$ significantly increased unesterified cholesterol, and to a greater degree, esterified cholesterol (Figure 1E). To evaluate whether $\mathrm{TNF} \alpha$ affects the ability of LDL to bind to the cells, ${ }^{125} \mathrm{I}$-LDL binding was performed. Figure $1 \mathrm{~F}$ shows that TNF $\alpha$ enhanced ${ }^{125} \mathrm{I}$-LDL surface releasable ${ }^{125} \mathrm{I}$-LDL at $4{ }^{\circ} \mathrm{C}$, after the cells were pre-treated at $37^{\circ} \mathrm{C}$. The amount released increased in the presence of 20 folds unlabeled LDL. This indicates that the ${ }^{125} \mathrm{I}$-LDL bound to some native LDL receptor. Further, cell-associated ${ }^{125}$ I-LDL was also higher on TNF $\alpha$-treated pHAECs (Figure 1G). 


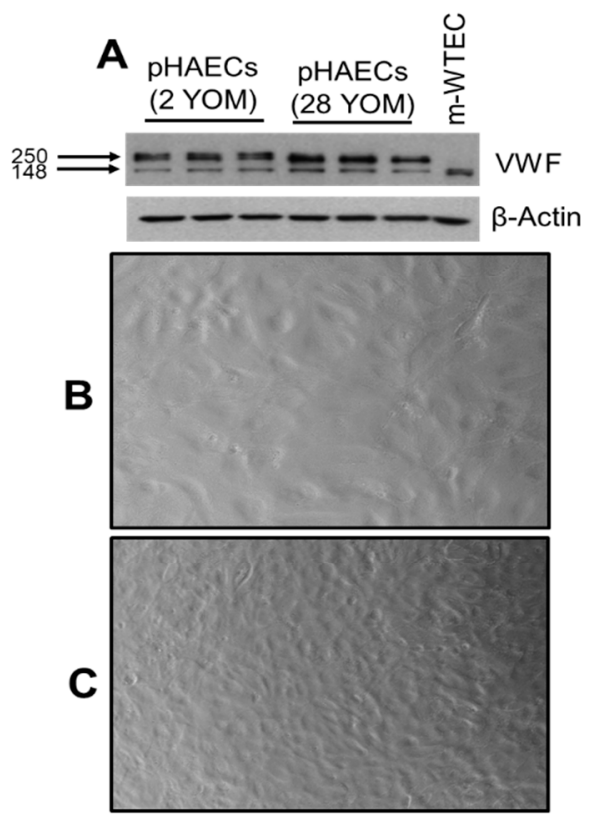

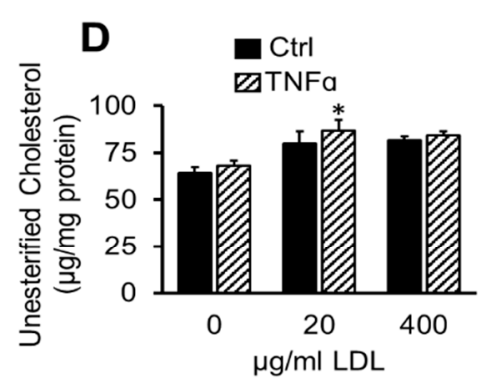

E

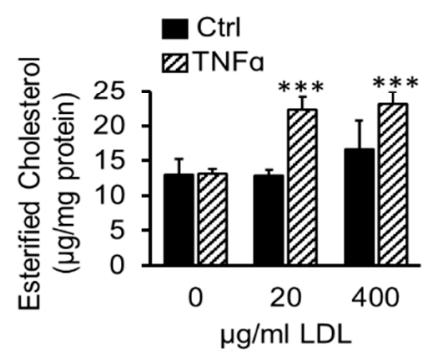

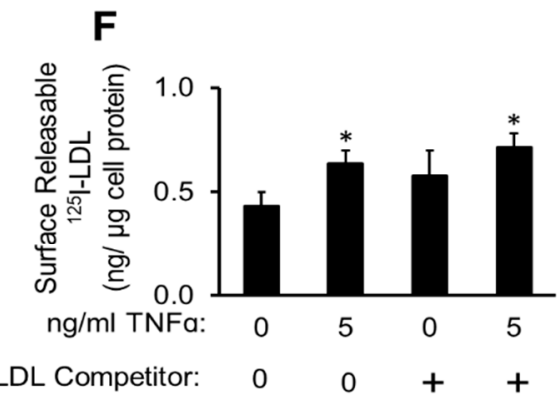

G

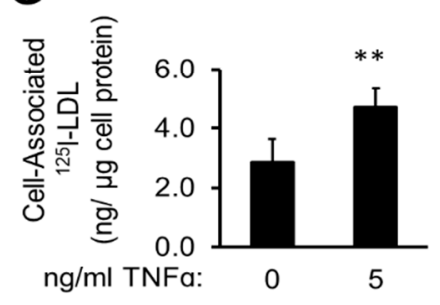

Figure 1. TNF $\alpha$ enhances cholesterol accumulation and LDL binding to pHAECs. (A) Expression of von Willebrand factor (VWF) by 2- or 28-year-old male (YOM) pHAECs, lots 70001318, 63233442, respectively. Mouse wild-type endothelial cells (m-WTEC) were used a comparison. (B,C) ranges of pHAEC confluency used. Images are at $20 \times$ magnification. (D-E) pHAECs were treated with the indicted concentration of human LDL without (Ctrl) or with $100 \mathrm{ng} / \mathrm{mL} \mathrm{TNF} \alpha$ for $24 \mathrm{~h}$. Unesterified cholesterol and cholesteryl esters were determined as described under Section 2. $n=5$. (F) Cells were pre-treated with 0 or $5 \mathrm{ng} / \mathrm{mL} \mathrm{TNF} \alpha$ in serum medium as described under Section 2 . After incubation at $37^{\circ} \mathrm{C}$, the amount of ${ }^{125} \mathrm{I}$-LDL released to serum-free medium at $4{ }^{\circ} \mathrm{C}$ without $(0)$ or with 20 folds unlabeled LDL competitor (+) was determined as the surface ${ }^{125} \mathrm{I}$-LDL. (G) The experiment was performed as in (E), and the amount of radioactivity associated with the cell was determined. $(\mathbf{C}, \mathbf{D}) n=3 .{ }^{*},{ }^{* *},{ }^{* *}, p<0.05,0.01,0.001$, relative to the corresponding Ctrl.3.2. ACAT inhibitor does not prevent TNF $\alpha$-induced LDL cholesterol accumulation.

It has been reported that TNF $\alpha$ induces cholesteryl ester accumulation in monocytes through enhanced ACAT activity in the presence of oxLDL [60]. To evaluate the extent to which enhanced ACAT activity is responsible in raising pHAEC cholesterol in the presence of LDL, the cells were treated with or without ACAT inhibitor, Sandoz 58-035. As reported in Figure 2A,B, the inhibition of ACAT activity slightly raised the unesterified cholesterol, and significantly suppressed cholesteryl ester accumulation. Despite this inhibition, the $\mathrm{TNF} \alpha$-induced total cholesterol accumulation, now mainly in the unesterified form, was not prevented (Figure 2A,C). ACAT inhibition also reduced the total cholesterol in the cells, with or without TNF $\alpha$ stimulation (Figure 2C). This is a known effect of ACAT inhibition. The higher elevated unesterified cholesterol is more likely to be effluxed from the cells than the esterified one [61].

\subsection{ACAT Inhibitor Does Not Prevent TNF $\alpha$-Induced LDL Cholesterol Accumulation}

It has been reported that TNF $\alpha$ induces cholesteryl ester accumulation in monocytes through enhanced ACAT activity in the presence of oxLDL [60]. To evaluate the extent to which enhanced ACAT activity is responsible in raising pHAEC cholesterol in the presence of LDL, the cells were treated with or without ACAT inhibitor, Sandoz 58-035. As is reported in Figure 2A,B, inhibition of ACAT activity slightly raised the unesterified cholesterol, and significantly suppressed cholesteryl ester accumulation. Despite this inhibition, the TNF $\alpha$ induced total cholesterol accumulation, now mainly in the unesterified form, was not prevented (Figure 2A,C). ACAT inhibition also reduced the total cholesterol in the cells, with or without TNF $\alpha$ stimulation (Figure 2C). This is a known effect of ACAT inhibition. The higher elevated unesterified cholesterol is more likely to be effluxed from the cells than the esterified one [61]. 

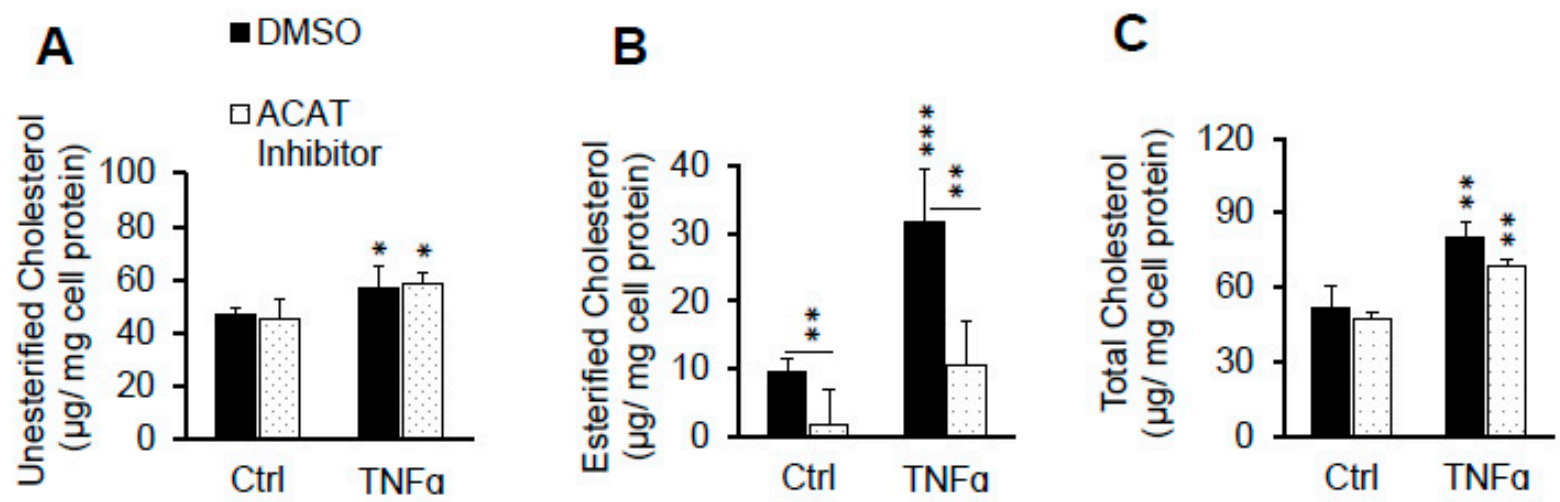

Figure 2. ACAT inhibitor does not prevent TNF $\alpha$-induced LDL cholesterol accumulation. Cells in serum-free medium were treated with 0 or $100 \mathrm{ng} / \mathrm{mL}$ TNF $\alpha$ in the presence of $0.1 \%$ DMSO (DMSO) or $10 \mu \mathrm{g} / \mathrm{mL}$ ACAT inhibitor (Sandoz 58-035) and $100 \mu \mathrm{g} / \mathrm{mL}$ LDL for $24 \mathrm{hrs}$. After washing with heparin as described under Materials and Methods, the cellular cholesterol content was determined. (A) unesterified cholesterol, (B) esterified cholesterol, and (C) total cholesterol. $n=3$. ${ }^{*},{ }^{* *}{ }^{* *}, p<0.05,0.01,0.001$, relative to corresponding Ctrl or as indicated with bars.

\section{3. $L D L$ Oxidation Is Not Required for TNF $\alpha$-Induced LDL Accumulation}

Having demonstrated that TNF $\alpha$ promoted LDL binding to pHAECs (Figure 1), the requirement for oxidative modification of LDL was investigated. Particularly, TNF $\alpha$ has been reported to promote release of the reactive oxygen species, superoxide and hydrogen peroxide $[62,63]$. Hence, experiments were performed to determine whether an oxidative modification of LDL is a prerequisite to TNF $\alpha$-induced LDL binding. To visualize TNF $\alpha$ induced LDL binding and subsequent internalization, Dil-LDL was used. Internalized Dil-LDL was significantly increased through $\mathrm{TNF} \alpha$ pre-treatment (Figure $3 \mathrm{~A}, \mathrm{~B})$. It can also be seen in Figure 3A,B that excess unlabeled native LDL blocked the binding and internalization of Dil-LDL, with and without $\mathrm{TNF} \alpha$ treatment. This demonstrates that native LDL components, and therefore receptors, are required for Dil-LDL binding and internalization. Excess unlabeled oxLDL, on the other hand, did not prevent Dil-LDL intracellular accumulation in control and $\mathrm{TNF} \alpha$-treated cells. Instead, there was a tendency of oxLDL to enhance intracellular Dil-LDL with or without TNF $\alpha$.
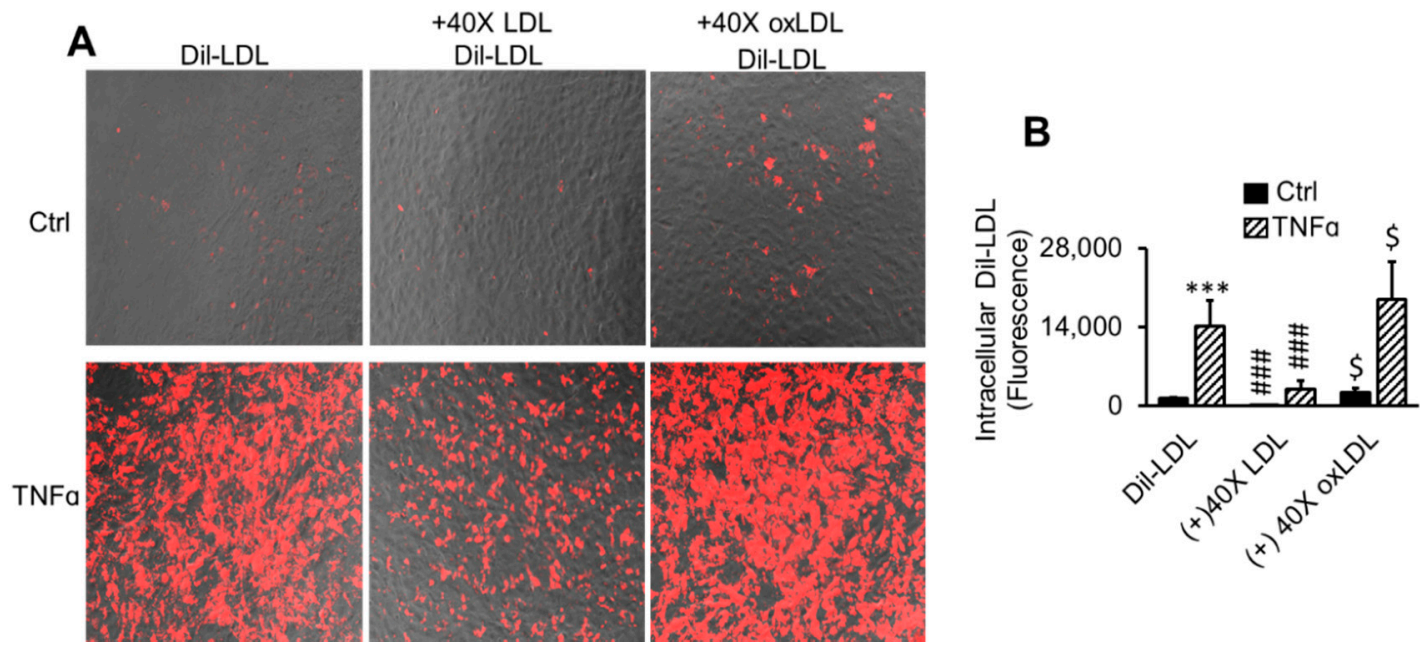

Figure 3. LDL oxidation is not required for TNF $\alpha$-induced LDL accumulation. (A,B) Cells were treated with 0 (Ctrl) or $100 \mathrm{ng} / \mathrm{mL} \mathrm{TNF} \alpha(\mathrm{TNF} \alpha)$ for $24 \mathrm{~h}$ in serum medium. The media were replaced with serum-free media in the continued presence of TNF $\alpha$ for $2 \mathrm{~h}$ to remove surface lipoproteins. Finally, $5 \mu \mathrm{g} / \mathrm{mL}$ Dil-LDL in serum-free medium (Dil-LDL) \pm 40 times LDL $(+40 \times$ LDL) or oxLDL $(+40 \times$ oxLDL) was added, followed by $3 \mathrm{~h}$ incubation. The images are $20 \times$ magnifications. $n=3 .{ }^{* * *}, p<0.001$ vs. Ctrl. $\$, \# \#, p<0.05,0.001$, relative to Dil-LDL alone. 


\subsection{TNF $\alpha$ Induces Massive Dil over [ $\left.{ }^{3} \mathrm{H}\right] C E$ Lipid Accumulation from LDL}

The lipids, Dil and ${ }^{3} \mathrm{H}$-cholesteryl esters $\left(\left[{ }^{3} \mathrm{H}\right] \mathrm{CE}\right)$, are stably fixed within LDL. To evaluate the ability of pHAECs to retain LDL hydrolysable $\left[{ }^{3} \mathrm{H}\right] \mathrm{CE}$ or the non-hydrolysable Dil, the cells were treated with increasing concentration of TNF $\alpha$ in the presence of $\left[{ }^{3} \mathrm{H}\right] \mathrm{CE}$ LDL or Dil-LDL. As shown in Figure $4 \mathrm{~A},{ }^{3} \mathrm{H}$-cholesterol accumulation derived from $\left[{ }^{3} \mathrm{H}\right] \mathrm{CE}-$ LDL was increased by about 2 folds with increasing TNF $\alpha$ concentration. On the other hand, Dil accumulation increased by about 50 folds (Figure 4B). Next, the cells were treated with increasing Dil-LDL concentration without (Figure 4C) or with TNF $\alpha$ (Figure 4D). As is shown in Figure 4C, $400 \mu \mathrm{g} / \mathrm{mL}$ Dil-LDL increased intracellular Dil level by about 50 folds compared to that at $1 \mu \mathrm{g} / \mathrm{mL}$ under control condition. Compared to Ctrl at $400 \mu \mathrm{g} / \mathrm{mL}$ Dil-LDL, TNF $\alpha$ increased the intracellular Dil by over 200 folds (Figure 4D).
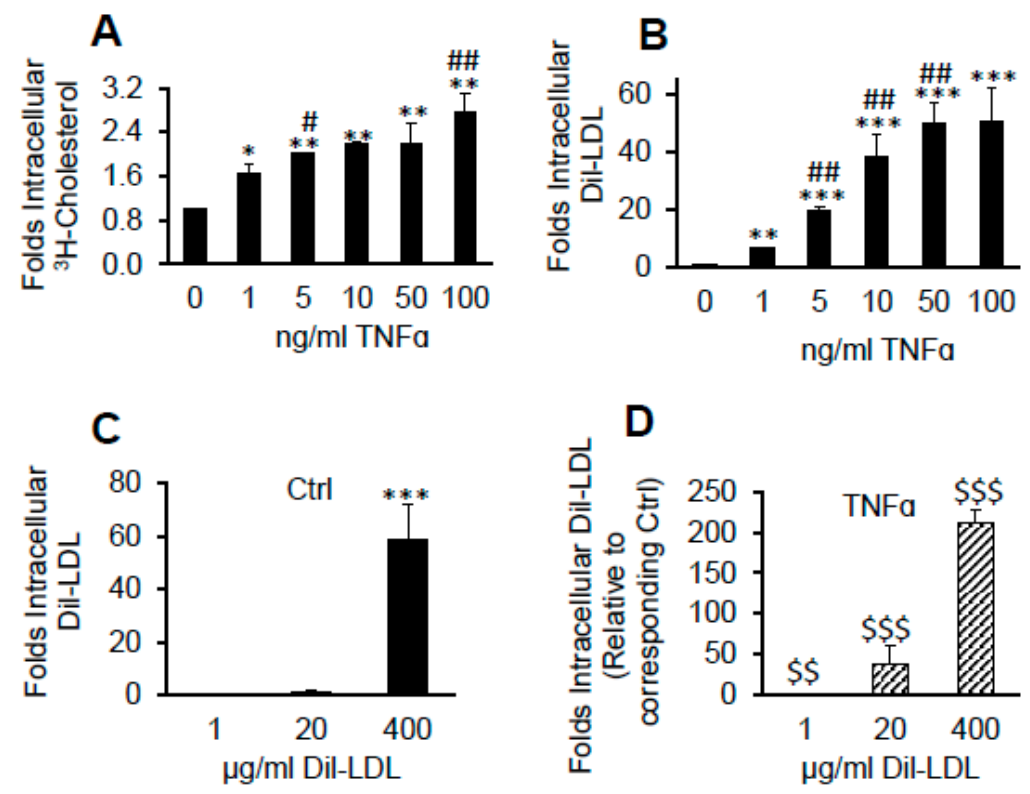

Figure 4. TNF $\alpha$ induces massive Dil over $\left[{ }^{3} \mathrm{H}\right] \mathrm{CE}$ lipid accumulation from LDL. pHAECs in serum medium were pre-treated with the indicated concentration of human TNF $\alpha$ for $24 \mathrm{~h}$. Subsequently, the cells were treated in the continued presence of the previous TNF $\alpha$ concentration and $50 \mu \mathrm{g} / \mathrm{mL}$ $\left[{ }^{3} \mathrm{H}\right] \mathrm{CE}-\mathrm{LDL}$ (A) or $5 \mu \mathrm{g} / \mathrm{mL}$ Dil-LDL (B) without serum for $24 \mathrm{~h}$. A, $n=4, \mathrm{~B}, n=3$. The cells were treated without (Ctrl), (C), or with $100 \mathrm{ng} / \mathrm{mL} \mathrm{TNF} \alpha(\mathbf{D})$, as above, in the presence of increasing concentration of Dil-LDL. $n=5 .{ }^{*}{ }^{* *},{ }^{* * *}, p<0.05,0.01,0.001$, relative to $0 \mathrm{ng} / \mathrm{mL} \mathrm{TNF} \alpha$ or $1 \mu \mathrm{g} / \mathrm{mL}$ Dil-LDL. \#, \#\#, $p<0.05,0.01$, vs. previous TNF $\alpha$ dose. $\$ \$, \$ \$, p<0.01,0.001$, relative to the corresponding Dil-LDL concentration under Ctrl condition.

\subsection{Lysosomal Inhibitor Enhances TNF $\alpha$-Induced LDL Lipid Accumulation}

The lowering of $\mathrm{pH}$ facilitates the disintegration and degradation of internalized LDL by low $\mathrm{pH}$-dependent lysosomal enzymes. This degradation is suppressed by the pH-raising compound, chloroquine [64]. To evaluate whether a similar phenomenon occurs in pHAECs, the cells were treated in the presence or absence of chloroquine. The presence of chloroquine caused the Dil to accumulate circumferentially within the cells, presumably in defective lysosomes (Figure 5A). As can be seen in Figure 5A,B, chloroquine greatly enhanced Dil-LDL accumulation without TNF $\alpha$. The presence of TNF $\alpha$ further increased the amount of chloroquine-induced cellular Dil-LDL. Chloroquine also increased ${ }^{3} \mathrm{H}$-cholesterol level from $\left[{ }^{3} \mathrm{H}\right] \mathrm{CE}$-LDL. However, it was not as pronounced as in the case of Dil (Figure 5C). 

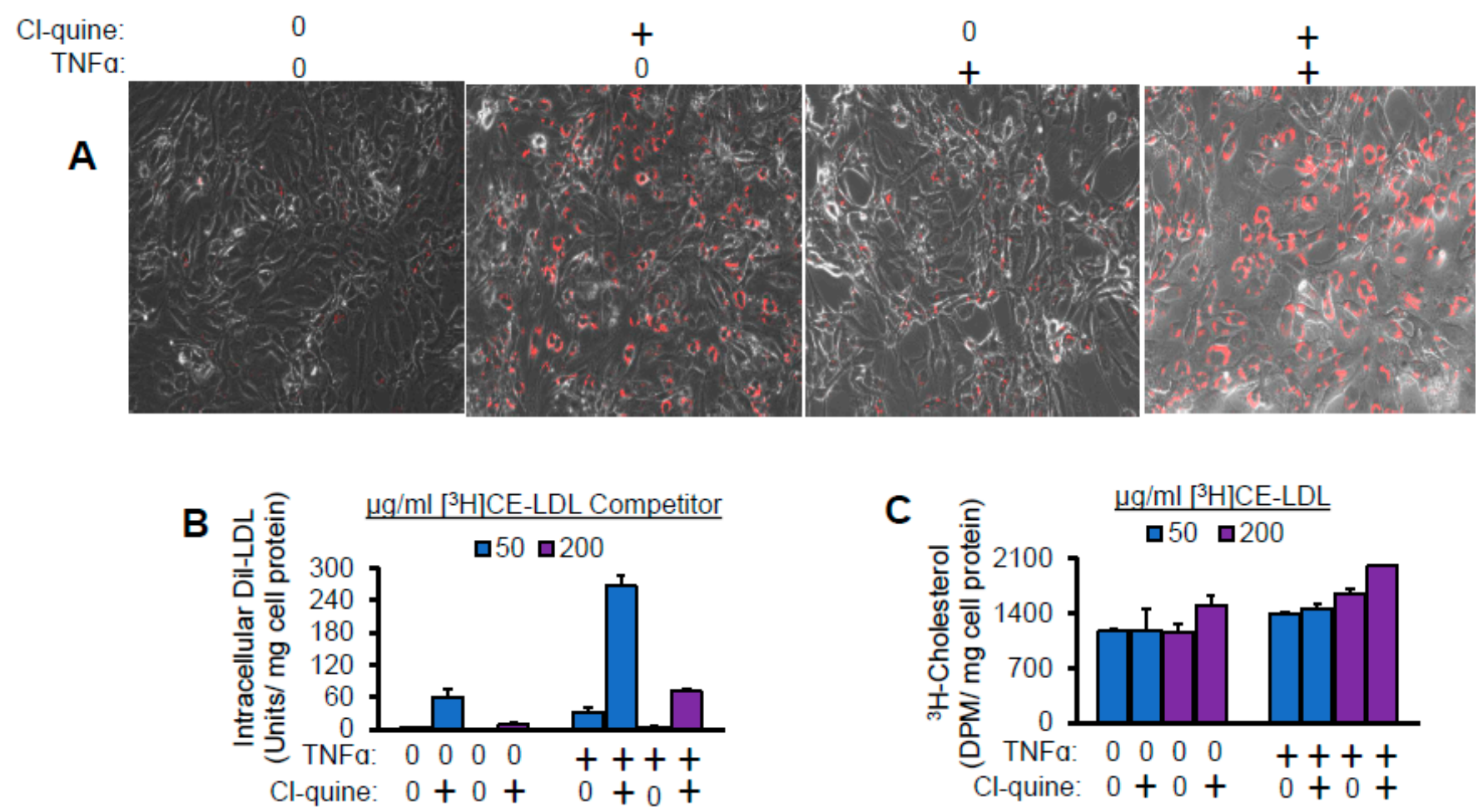

Figure 5. Lysosomal inhibitor enhances TNF $\alpha$-induced LDL lipid accumulation. The cells were pre-treated with 0 or $100 \mathrm{ng} / \mathrm{mL} \mathrm{TNF} \alpha(+)$ for $24 \mathrm{~h}$ in the presence of serum. Subsequently, in the continued presence of TNF $\alpha$, the cells were treated with $0.5 \mu \mathrm{g} / \mathrm{mL}$ Dil-LDL, plus 50 or $200 \mu \mathrm{g} / \mathrm{mL}\left[{ }^{3} \mathrm{H}\right] \mathrm{CE}-\mathrm{LDL}$, and containing 0 or $50 \mu \mathrm{M}$ chloroquine diphosphate (Cl-quine), +, a lysosomal blocker, without serum. After $24 \mathrm{~h}$, the intracellular fluorescence (A,B) or radioactivity (C) was determined. The separation of \#cells in A is an artificact of preparation prior to lysing the cells for radioactivity. The circumferential accumulation of the Dil-LDL in the presence of chloroquine is apparent (A). The images are $20 \times$ magnifications. $n=2$.

\subsection{ApoE Is Not Required for TNF $\alpha$-Induced Dil-LDL Accumulation}

Apolipoprotein B (apoB) is the major protein in LDL [65]. However, variable amounts of apoE are also present in LDL [66]. Since apoE plays a major role in binding several lipoprotein receptors of the LDLR family $[67,68]$, the effect of apoE depletion on TNF $\alpha$ induced Dil-LDL intracellular levels was investigated. The successful depletion of apoE from Dil-HDL3 and Dil-LDL can be seen in Figure 6A. That both HDL3 and LDL contain apoE, while apoA1 and apoB are present in significant amounts only in HDL3 and LDL, respectively, is apparent in the figure. Data in Figure 6A also show that apoE represented a small proportion of the total LDL particle, but a larger fraction in HDL3. The apoB protein is nearly equal with or without apoE depletion, whereas apoA1 is noticeable less. That equal protein was loaded is presented in the Supplementary Material, Figure S3. In Figure $6 \mathrm{~B}$, it can be seen that the isolation procedure did not inhibit the ability of TNF $\alpha$ to induce Dil-LDL accumulation. Further, apoE depletion had no effect in this regard.

\subsection{TNF $\alpha$-Induced Dil-LDL Accumulation Is Blocked by Specific LDLR Antibody}

Having found evidence that TNF $\alpha$ promotes cholesterol accumulation in pHAECs through the endocytosis of native LDL, I next investigated what members of the LDLR family are responsible. As can be seen in Figure 7A, the pan-LDLR family blocker PCSK9 [69-71], but not RAP [72], suppressed the Dil-LDL accumulation. To investigate the contribution of LDLR in mediating TNF $\alpha$-induced Dil-LDL accumulation, an LDLR antibody was investigated for its specificity and function in pHAECs treated with or without TNF $\alpha$. As can be seen in Figure 7B, the antibody recognized a single protein consistent with the expected migration position of LDLR. It can be seen that incubation of 
TNF $\alpha$-treated cells with the antibody induced an upward migratory shift in LDLR protein to a larger extent than in control cells. Attempts to directly detect the LDLR antibody were unsuccessful, suggesting that the shift is due to another interaction or modification.

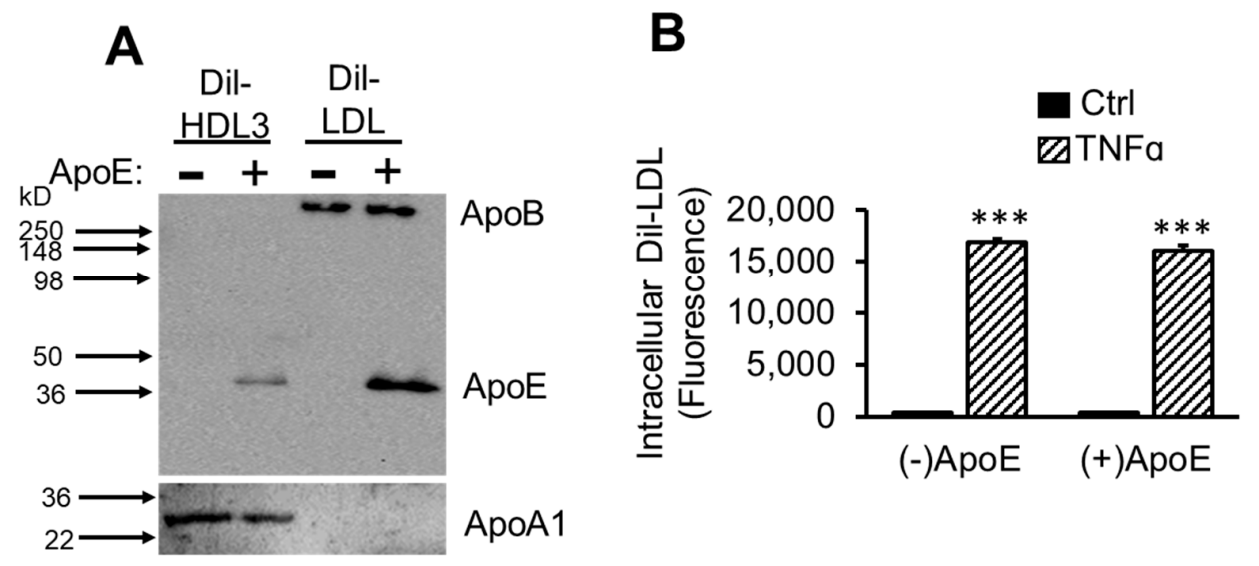

Figure 6. ApoE is not required for TNF $\alpha$-induced Dil-LDL accumulation. (A) Dil-HDL3 or Dil-LDL was depleted of apoE (-), or apoE was retained (+) as described under Section 2. The presence of apoB and apoE were determined by immunoblotting 0.5 and $1 \mu \mathrm{g} / \mathrm{mL}$ Dil-HDL3 and Dil-LDL, respectively. (B) pHAECs were treated $\pm 100 \mathrm{ng} / \mathrm{mL} \mathrm{TNF} \alpha$ in serum medium for $24 \mathrm{~h}$. Following $2 \mathrm{~h}$ incubation in serum free medium, in the continued presence of TNF $\alpha$, the cells were incubated with $2.5 \mu \mathrm{g} / \mathrm{mL}$ Dil-LDL without (-) or with apoE (+) for $3 \mathrm{~h} . n=3{ }^{* * *}, p<0.001$, relative to Ctrl.
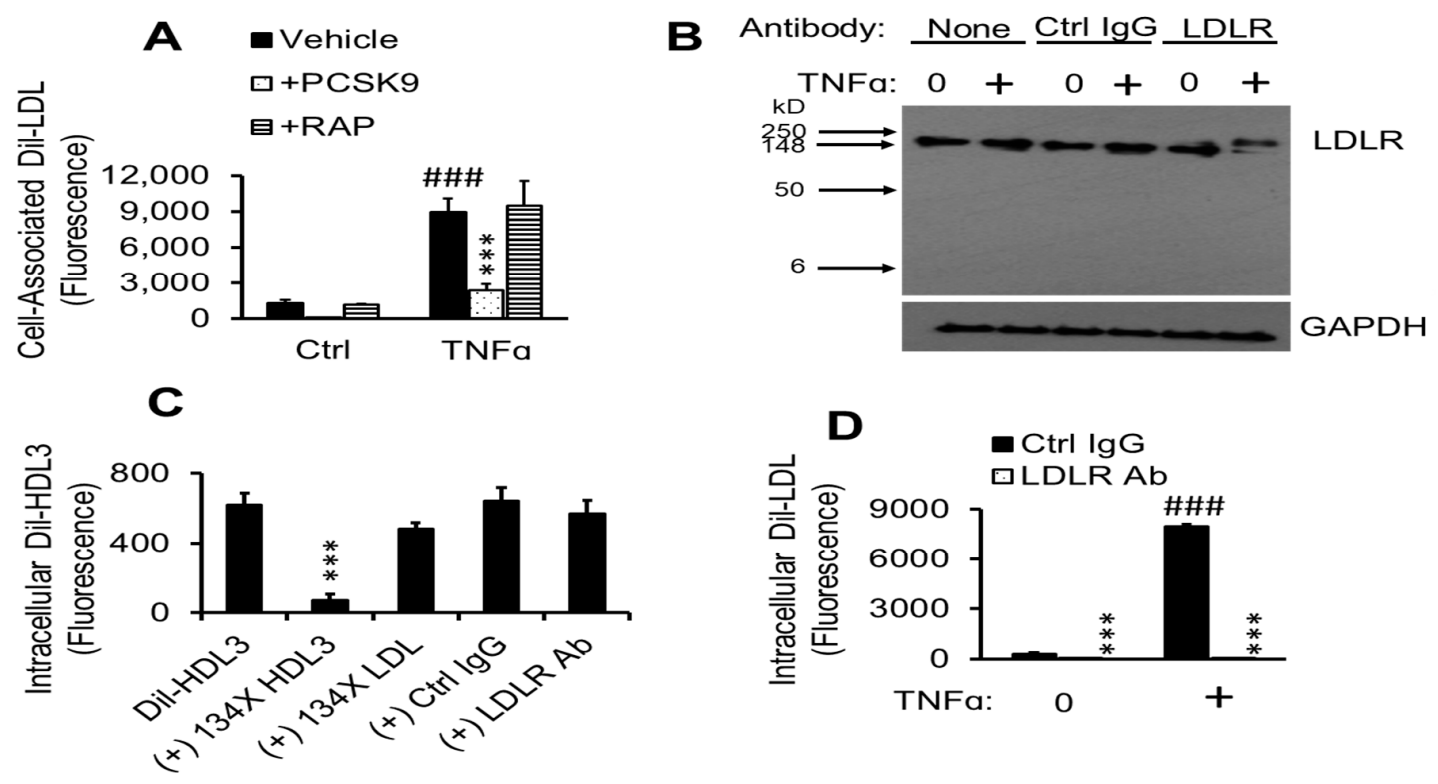

Figure 7. TNF $\alpha$-induced Dil-LDL accumulation is blocked by specific LDLR antibody. (A) pHAECs in serum medium were pre-treated with 0 (Ctrl) or $100 \mathrm{ng} / \mathrm{mL} \mathrm{TNF} \alpha$ for $24 \mathrm{~h}$. Afterwards, the cells were cultured in the presence of vehicle, $12.5 \mu \mathrm{g} / \mathrm{mL}$ human PCSK9 (ApoER, LDLR, LRP, and VLDLR inhibitors), or $21 \mu \mathrm{g} / \mathrm{mL}$ human RAP (ApoER2, LRP, and VLDLR inhibitors) in serum-free medium for $1 \mathrm{~h}$. Lastly, $8 \mu \mathrm{g} / \mathrm{mL}$ Dil-LDL was added, followed by $4 \mathrm{~h}$ incubation. $n=3$. $\# \# \#, * * *, p<0.001$ vs. Ctrl vehicle and TNF $\alpha$ vehicle, respectively. (B), Cells were cultured in serum medium $\pm 100 \mathrm{ng} / \mathrm{mL}$ $\mathrm{TNF} \alpha$, followed by $3 \mathrm{~h}$ incubation in serum-free medium in the continued presence of TNF $\alpha(+)$ without antibody (None), $18 \mu \mathrm{g} / \mathrm{mL}$ control IgG (Ctrl Ig) or LDLR antibody (LDLR), then immunoblotted for LDLR and GAPDH. $n=3$. (C), pHAECs were cultured in serum-free medium for $2 \mathrm{~h}$, followed by incubation with $5 \mu \mathrm{g} / \mathrm{mL}$ Dil-HDL3 with (+) 134× unlabeled HDL3, LDL, $20 \mu \mathrm{g} / \mathrm{mL}$ control IgG (Ctrl IgG) or LDLR antibody (LDLR Ab), as indicated. $n=6 .{ }^{* * *}, p<0.001$ vs. Dil-HDL3. (D) Cells were cultured in serum medium with 0 or $100 \mathrm{ng} / \mathrm{mL} \mathrm{TNF} \alpha(+)$, followed by $2 \mathrm{~h}$ incubation in serum-free medium in the continued presence of TNF $\alpha$. Subsequently, $5 \mu \mathrm{g} / \mathrm{mL}$ Dil-LDL in the presence of $20 \mu \mathrm{g} / \mathrm{mL}$ control IgG (Ctrl IgG) or LDLR antibody (LDLR Ab) was added. Note that the values for LDLR Ab are very low compared to others. $n=8$. \#\#\#, ${ }^{* * *}, p<0.001$ vs. corresponding $0 \mu \mathrm{g} / \mathrm{mL}$ TNF $\alpha$ and $\mathrm{Ctrl} \operatorname{IgG}$, respectively. 
HDL3 critically depends on non-LDLR mechanisms for uptake, especially in the absence of apoE [73]. Thus, to further evaluate the specificity of the LDLR antibody, intracellular uptake of Dil-HDL3 was measured. As can be seen in Figure 7C, intracellular Dil-HDL3 levels were significantly blocked by excess unlabeled HDL3, whereas that of LDL only had a mild effect. Further, the LDLR antibody did not block intracellular Dil-HDL3 to a considerable level. In contrast, the LDLR antibody blocked intracellular Dil-LDL accumulation (Figure 7D). This blockage was greater than $99 \%$ in $\mathrm{TNF} \alpha$-treated cells.

\subsection{TNF $\alpha$ Upregulates Cell Surface LDLR Protein}

Having determined that LDLR is responsible for TNF $\alpha$-induced LDL accumulation in pHAECs, I next tested whether the total and surface LDLR is changed by TNF $\alpha$. As can be seen in Figure $8 \mathrm{~A}, \mathrm{D}, \mathrm{TNF} \alpha$-induced an upregulation of the LDLR protein total and surface by about $90 \%$ and $138 \%$, respectively. ABCA1 (Figure 8A,B) and ICAM-1 (Figure 8A,C) proteins, both of which have been reported to be induced by TNF $\alpha$ treatment $[32,74,75]$, were found to be significantly increased as well. A low molecular weight form of ABCA1, however, was primarily induced in $\mathrm{TNF} \alpha$-treated cells. In contrast, scavenger receptor B1 (SR-B1) was downregulated by TNF $\alpha$ (Figure 8A,E). Similar findings have been reported on hepatocytes [76]. Figure 8A also shows that the intracellular proteins GAPDH were undetectable at the cell surface. Although caveolin- 1 has been reported to be closely associated with the inner plasma membrane $[77,78]$, it was not detected in the cell surface assay. This indicates that the outer plasma membrane proteins were selectively labeled.

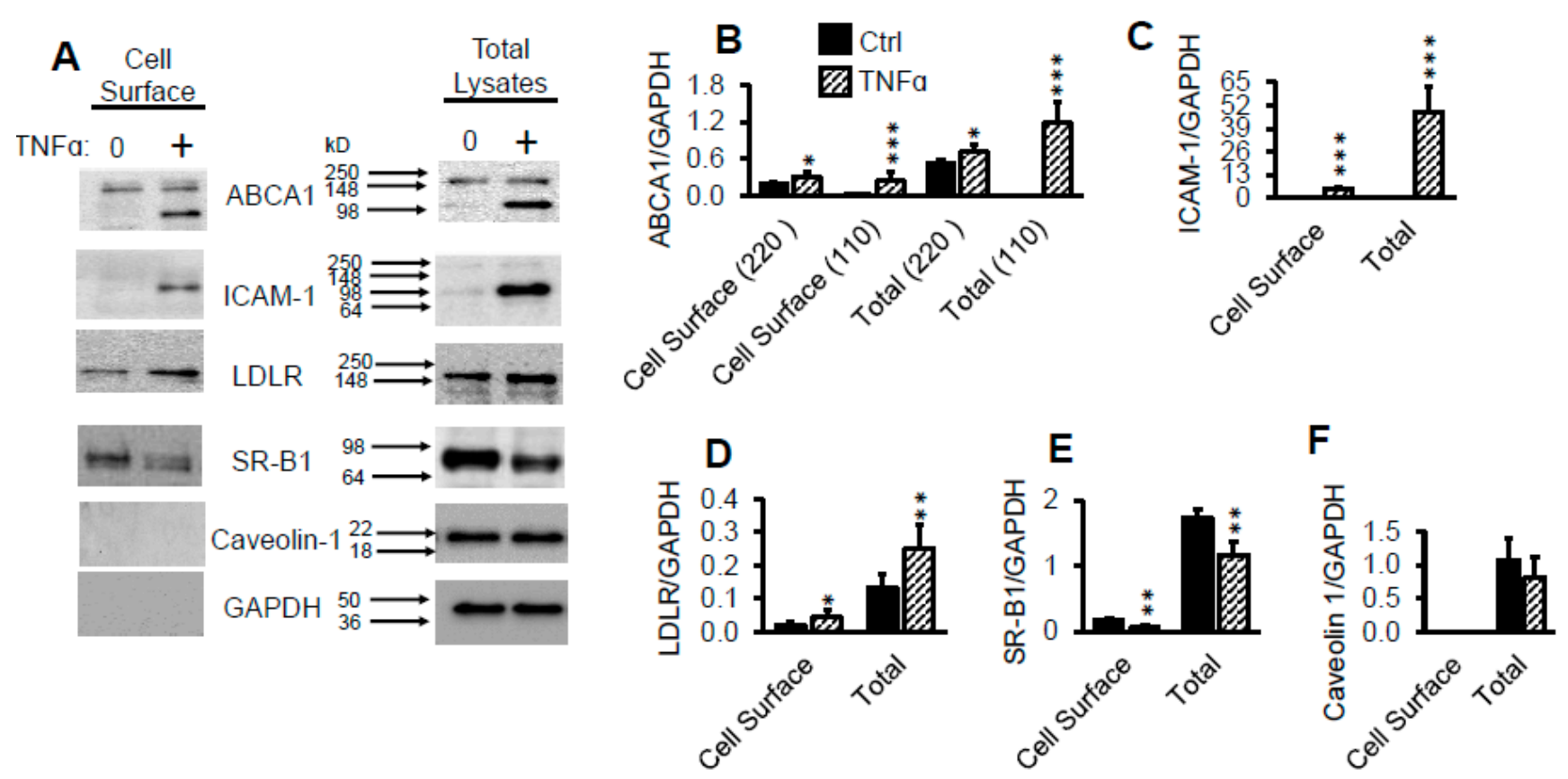

Figure 8. TNF $\alpha$ upregulates cell surface LDLR protein. (A-F), Confluent pHAECs in serum medium were pre-treated with 0 or $100 \mathrm{ng} / \mathrm{mL} \mathrm{TNF} \alpha(+)$ for $24 \mathrm{~h}$ in serum medium. The cells were then treated and lysed for total (Total Lysates) and biotinylated cell surface (Cell Surface) proteins, as explained under Materials and Methods, Section 4.14. ABCA1 bands $(\mathbf{A}, \mathbf{B})$ at $\sim 220$ and $110 \mathrm{kD}$ are indicated. $n=3 .{ }^{*}, * * * * *, p<0.05,0.01,0.001$, vs. corresponding Ctrl.

\subsection{TNF $\alpha$ Promotes Rapid Association of LDLR with Its Antibody}

To evaluate the consequence of the increase in cell surface LDLR induced by TNF $\alpha$ on the association and entry of LDLR antibody, immunofluorescence studies were performed. As can be seen in Figure 9A, TNF $\alpha$ did not enhance the association of control antibody with the cells, but significantly induced association with the specific LDLR antibody by $30 \mathrm{~min}$ at $37^{\circ} \mathrm{C}$. This indicates that TNF $\alpha$ did not promote non-selective endocytic processes. The 
surface distribution of LDLR (arrows) and the internalization of the surface LDLR (arrow heads) in cells treated with TNF $\alpha$ can be seen in Figure 9B.
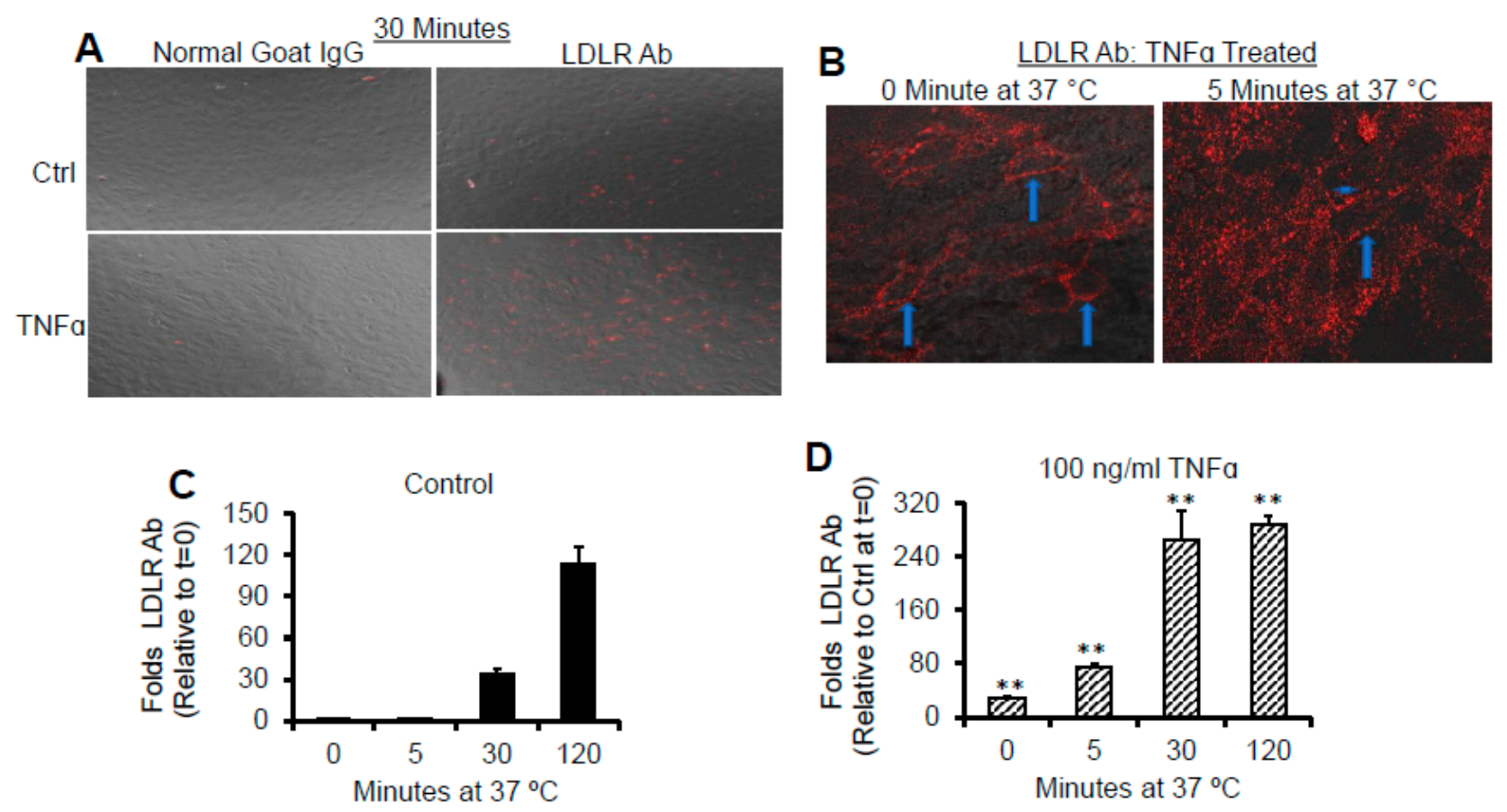

Figure 9. TNF $\alpha$ promotes rapid association of LDLR with it antibody. pHAECs in serum medium were pre-treated with 0 (Ctrl) or $100 \mathrm{ng} / \mathrm{mL} \mathrm{TNF} \alpha(\mathrm{TNF} \alpha)$ for $24 \mathrm{~h}$. Subsequently, in the continued presence of TNF $\alpha$, the media were replaced with $5 \mu \mathrm{g} / \mathrm{mL}$ control normal goat IgG or LDLR antibody (LDLR Ab) for $0,5,30$, or $120 \mathrm{~min}$ at $37^{\circ} \mathrm{C}$. The surface-accessible LDLR was then determined as detailed under Experimental Procedures. (A) $20 \times$ objective magnification of LDLR detected after $30 \mathrm{~min}$. (B) $40 \times$ confocal detection of LDLR in TNF $\alpha$-treated pHAECs at 0 and $5 \mathrm{~min}$. The arrows show the membrane distribution of the LDLR in focus, while the arrowhead shows internalized LDLR. (C) Surface-accessible LDLR as a function of time under control condition. (D) As C, in the presence of TNF $\alpha . n=4 .{ }^{* *}, p<0.01$ relative to control at the same time.

\subsection{Antioxidant Suppresses TNF $\alpha$-Induced Dil-LDL Accumulation}

$\mathrm{TNF} \alpha$ signaling cascade involves multiple mediators, among which are the transcription factor, NF- $\mathrm{KB}$, and apoptosis signal-regulating kinase 1 (ASK1), an upstream mediator of JNK and p38 [79], that facilitate apoptosis. To evaluate whether these proteins are upstream in the TNF $\alpha$-induced Dil-LDL accumulation, experiments were performed in the presence of their respective inhibitors. As can be seen in Figure 10A, the inhibitors did not suppress the action of TNF $\alpha$. In contrast, the antioxidant, TMTU, inhibited this effect with increasing doses (Figure 10B). 

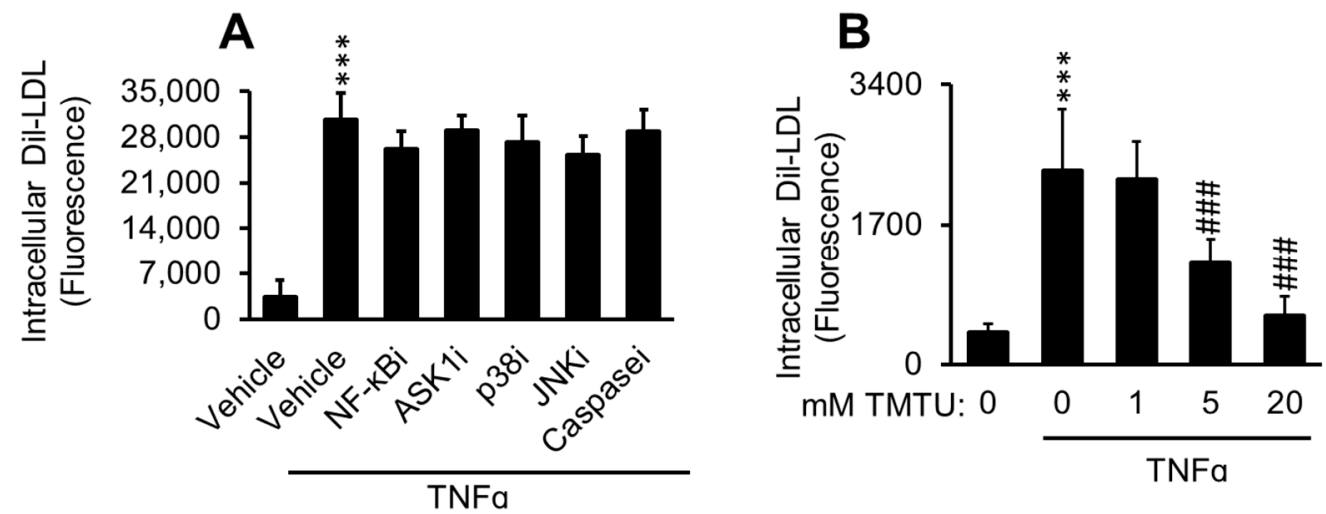

Figure 10. Antioxidant suppresses TNF $\alpha$-induced Dil-LDL accumulation. (A) pHAECs were pre-treated with $0.05 \%$ DMSO (Vehicle) or TNF $\alpha$-cascade inhihitors, as indicated: NF-kBi $(25 \mu \mathrm{M})$. Two different forms were tested. ASK1i $(5 \mu \mathrm{M})$, p38i $(1 \mu \mathrm{M})$, JNKi $(5 \mu \mathrm{M})$, or pan-caspase inhibitor, Caspasei $(5 \mu \mathrm{M})$ for $30 \mathrm{~min}$ in serum-free medium. Subsequently, serum-free $3 \mu \mathrm{g} / \mathrm{mL}$ Dil-LDL, with $100 \mathrm{ng} / \mathrm{mL} \mathrm{TNF} \alpha$, as indicated, was added, followed by $24 \mathrm{~h}$ incubation. $n=3$. (B) Cells were treated with $1 \%$ DMSO vehicle with $100 \mathrm{ng} / \mathrm{mL} \mathrm{TNF} \alpha$ as indicated, in the presence of $0,1,5$, or $20 \mathrm{mM} \mathrm{TMTU}$ and $3 \mu \mathrm{g} / \mathrm{mL}$ Dil-LDL. Subsequently, the cells were cultured for 24 h. $n=4$. ${ }^{* * *}$, \#\#, $p<0.001 \mathrm{vs.} 0 \mu \mathrm{g} / \mathrm{mL}$ TNF $\alpha$ and $0 \mathrm{mM}$ TMTU in the presence of $\mathrm{TNF} \alpha$, respectively.

\subsection{TNF $\alpha$ Does Not Affect AP to BL Release of Degraded LDL Protein}

To address the effect of increased LDLR-mediated uptake of LDL on apical to basolateral LDL protein transport, the pHAECs were grown to confluence on Transwell inserts, as shown in Figure 11A. ${ }^{125}$ I-LDL detected in the BL medium was either non-intact (Figure 11B) or intact (Figure 11C). In Figure 11B, it is shown that unlabeled LDL competitor reduced the amount of non-intact ${ }^{125} \mathrm{I}-\mathrm{LDL}$, indicating release in a receptor-dependent manner. This was TNF $\alpha$-independent. In contrast, the unlabeled competitor had no effect on the intact ${ }^{125} \mathrm{I}$-LDL measured in the BL medium (Figure 11C). TNF $\alpha$ tended to enhance BL release of intact ${ }^{125} \mathrm{I}$-LDL, consistent with enhanced cell-cell permeability. The overall data thus indicate that the LDLR protein cargo is not efficiently trafficked in a polarized manner in pHAECs.
A
Release to BL medium

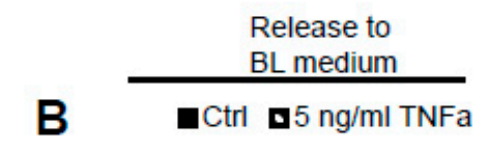
Release to BL medium

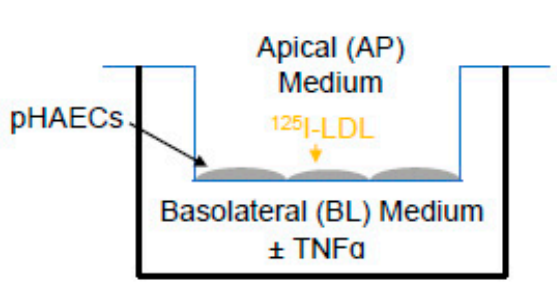

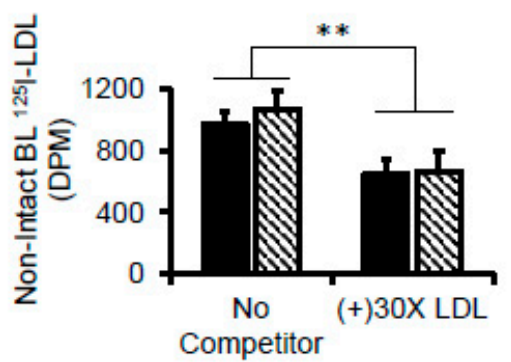

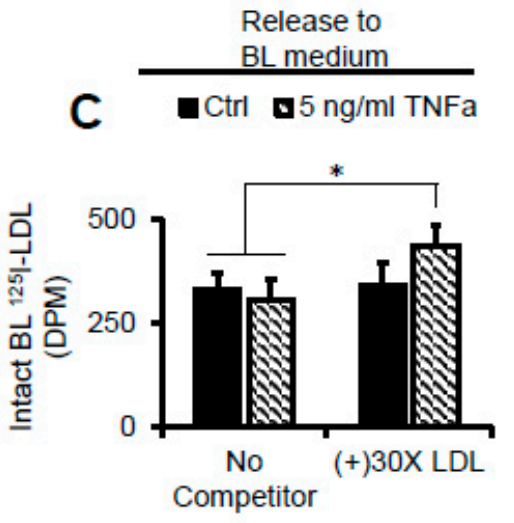

Figure 11. TNF $\alpha$ does not affect AP to BL release of degraded LDL protein. (A) Diagram of the experimental setup in (B,C) in which pHAECs were grown to confluence on $3 \mu \mathrm{m}$ (pore size) polycarbonate filters, with ${ }^{125}$ I-LDL in the AP medium. (B) pHAECs in serum medium were pre-treated with 0 (Ctrl) or $5 \mathrm{ng} / \mathrm{mL} \mathrm{TNF} \alpha$ on the BL side for $48 \mathrm{~h}$ as described under Materials and Methods, Transwell Insert Experiments. Under serum-free conditions, $10 \mu \mathrm{g} / \mathrm{mL}{ }^{125} \mathrm{I}$-LDL was added to the AP side (No Competitor) or with 30 folds unlabeled LDL, (+) $30 \times \mathrm{LDL}$, in the continued presence of TNF $\alpha$. After $3 \mathrm{~h}$, the BL media were collected, and non-intact ${ }^{125}$ I-LDL was measured as described under Experimental Procedures. (C) The experiment was performed as in B, followed by detection of intact BL ${ }^{125}$ I-LDL. $n=3 .{ }^{*}, * *, p<0.05,0.01$, respectively. 


\subsection{TNF $\alpha$ Does Not Affect AP to BL LDL Lipid Release}

To determine whether LDLR facilitates AP to BL LDL lipid transport, the pHAECs on Transwell inserts were incubated with LDL colabeled with Dil and ${ }^{3} \mathrm{H}$-cholesteryl esters (Figure 12A,B). As can be seen in the figures, TNF $\alpha$ dose-dependently increased the accumulation of Dil-LDL on the pHAECs grown on Transwell inserts, in the same manner as those grown on plastic dishes. Similar to pHAECs on plastic dishes, the LDLR antibody significantly blocked the TNF $\alpha$-induced uptake of Dil-LDL by pHAECs grown on Transwell inserts by over $99 \%$. The corresponding uptake of ${ }^{3} \mathrm{H}$-cholesteryl esters is shown in Figure 12C. The ${ }^{3} \mathrm{H}$-cholesteryl ester accumulation induced by TNF $\alpha$ is blocked in the presence of antibody against LDLR. Surprisingly, LDLR blockage had no effect on the amount of measurable ${ }^{3} \mathrm{H}$-choleseryl ester detectable in the BL medium (Figure 12D). This is consistent with the BL Dil-LDL, whose value was independent of TNF $\alpha$ treatment (Figure 12E).
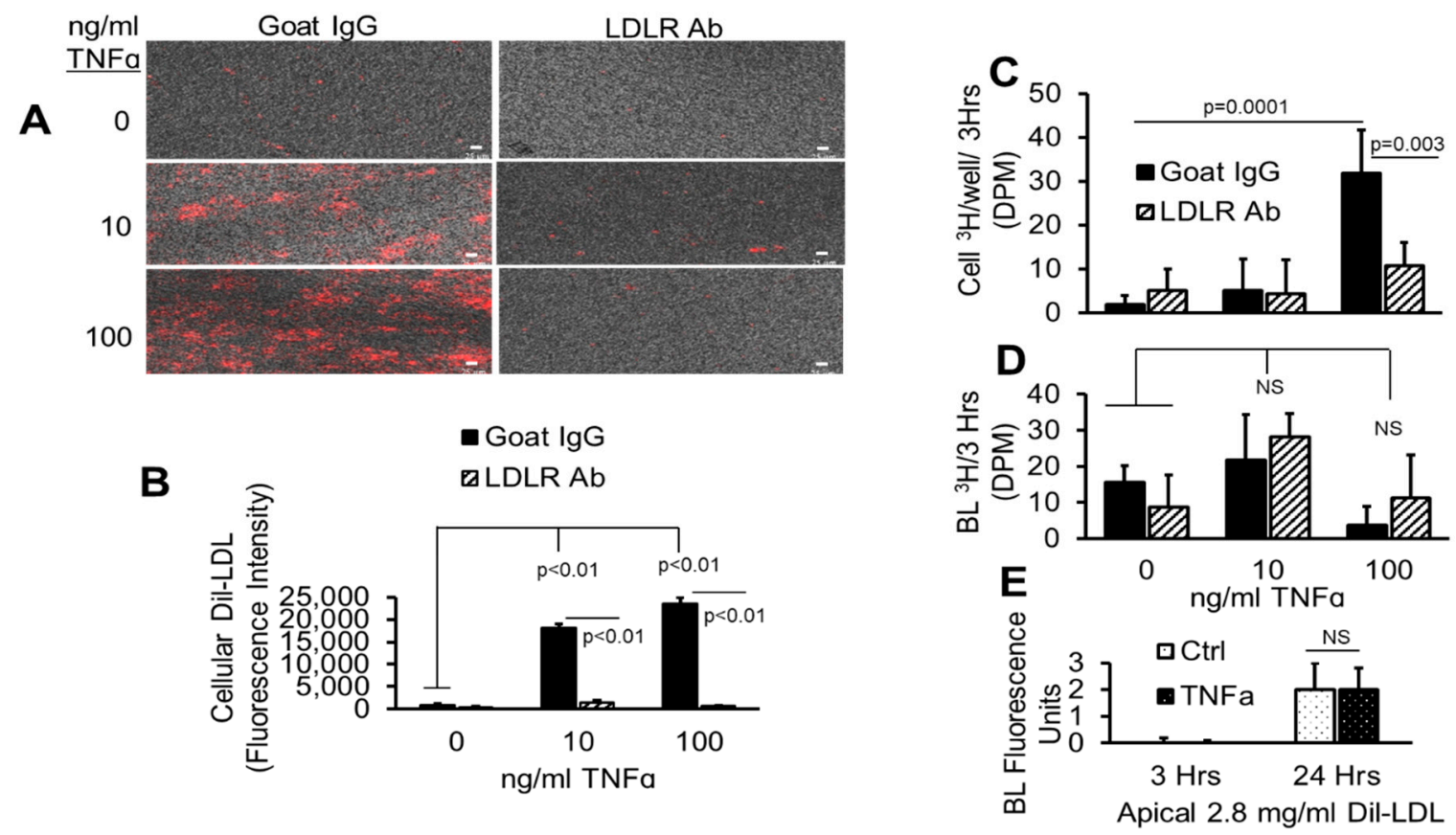

Figure 12. TNF $\alpha$ does not affect AP to BL LDL lipid release. (A-D) pHAECs were pre-treated as in Figure 11 with 0, 10, or $100 \mathrm{ng} / \mathrm{mL}$ TNF $\alpha$ for $24 \mathrm{~h}$ in serum. Subsequently, $20 \mu \mathrm{g} / \mathrm{mL}$ control normal goat IgG (Goat IgG) or LDLR antibody (LDLR $\mathrm{Ab}$ ) was added to the AP medium without serum for $2 \mathrm{~h}$. Finally, $1.6 \mathrm{mg} / \mathrm{mL}$ double labeled Dil, $\left[{ }^{3} \mathrm{H}\right] \mathrm{CE}-\mathrm{LDL}$ was added to the AP medium for $3 \mathrm{~h}$. After heparin wash, the intracellular fluorescence $(\mathbf{A}, \mathbf{B}),{ }^{3} \mathrm{H}$ radioactivity $(\mathbf{C})$, or medium $\mathrm{BL}{ }^{3} \mathrm{H}(\mathbf{D})$ was determined. (E) The cells were treated for 3 or $24 \mathrm{~h}$ with 0 (Ctrl) or $100 \mathrm{ng} / \mathrm{mL} \mathrm{TNF} \alpha$ without serum in the presence of apical Dil-LDL, and the BL fluorescence was determined. $n=3$.

\section{Discussion}

The modification of LDL, producing derivatives with receptors present or inducible on macrophages or smooth muscle cells drives foam cell formation. Thus, LDL modification due to oxidation [80], aggregation [81], or complex formation with proteoglycans [82-85] is known promote macrophage foam cells. The present results demonstrate that native LDL can itself induce excess lipid accumulation in endothelial cells, independent of modification, in the presence of TNF $\alpha$. The data suggest that pHAECs, like macrophages, may be susceptible to changes related to excess cholesterol loading and may facilitate the progression of atherosclerotic lesion in the continued presence of elevated LDL or apoB-containing lipoproteins, which enters cells through the LDLR.

Excess cholesterol or lipids in arterial endothelial may to lead to endothelial dysfunction due, in part, to space and membrane disruption [86]. The reduction of serum LDL 
cholesterol to or below $100 \mathrm{mg} / \mathrm{dl}$ has been shown to reduce the negative consequences of atherosclerosis [87]. The general upregulation of the LDLR receptor function through inhibition of PCSK9 has been reported to benefit against atherosclerotic coronary artery disease $[88,89]$. Notwithstanding, PCSK9 also downregulates other receptors in the LDLR family $[70,71]$, and binds the scavenger receptor, CD36, concurrent with thrombosis $[88,90]$. The benefit of targeting PCSK9 to upregulate LDLR in the liver, thereby reducing serum $\mathrm{LDL}$, is obvious for those with atherosclerotic cardiovascular diseases for which other strategies are ineffective. My results suggest, however, that additional tissue specificity may be required, particularly if therapy fails to reduce serum non-HDL lipoproteins below optimal levels. Specifically, elevated non-HDL lipoprotein concentration in the setting of elevated LDLR may disrupt the normal function of arterial endothelial cells, and perhaps other cells.

The data from this report indicate that pHAECs have efficient mechanism(s) of getting rid of LDL-derived cholesterol. TNF $\alpha$ induced about 25 folds intracellular Dil-LDL compared to $\left[{ }^{3} \mathrm{H}\right] \mathrm{CE}-\mathrm{LDL}$. Thus, it appears that pHAECs are normally protected against LDL-derived cholesterol accumulation by keeping cell surface LDLR down, combined with efficient efflux mechanisms. The TNF $\alpha$-induction of ABCA1 (Figure 8), which mediates cholesterol efflux, suggest that ABCA1 may be involved. However, the significance of an apparently truncated form (Figure 8A) is unclear. The tendency of TNF $\alpha$ to induce ABCA1 expression in some cell types has also been published by others. Specifically, it has been reported that TNF $\alpha$ enhances cholesterol efflux and ABCA1 mRNA and protein through NF-kB signaling [75] in macrophages, and possibly adipocytes [91]. However, as is often characteristic of the complex nature of TNF $\alpha$ signaling, it has also been reported to downregulate ABCA1 in hepatocytes [92], Caco-2 intestinal cell [93], and osteocytes [94].

$\mathrm{TNF} \alpha$ is a pleiotropic autocrine and paracrine mediator important in multiple signaling cascades that range from activating immune cells to fight viruses, bacteria, and cancer cells, to promoting entry of monocytes and lymphocytes into atherosclerotic lesions $[4,95,96]$. The latter process is recognized to be pro-atherogenic. TNF $\alpha$ has also been reported to play an important role in the current COVID-19 pandemic [97]. Thus, nonspecific disruption of TNF $\alpha$ activity in the animal interferes with many important biological functions [98]. It has also been reported that TNF $\alpha$ upregulates LDLR in hepatocytes [92]. My finding that TNF $\alpha$ upregulates surface LDLR function in pHAECs implies that it is possible to regulate this process selectively, while leaving the beneficial functions of TNF $\alpha$ intact.

It has been reported that AP to BL LDL transport occurs in vivo across arterial endothelial cells [99]. The findings from this report suggest that this transport is probably not through LDLR, as lysosome inhibition (Figure 5) significantly promoted Dil-LDL accumulation with or without TNF $\alpha$. SR-BI, on the other hand, has been reported to faciliate AP to BL transport of LDL in an LDLR-independent manner [100]. However, there is some controversy about the role of LDLR in trafficking ligand across the brain endothelium. Thus, it has been reported that LDLR mediates transcytosis of LDL and its ligand in brain microvascular endothelial cells [101] in vitro. However, studies using animal models suggest that LRP and very low-density lipoprotein receptor (VLDLR), not LDLR, are responsible for the transcytosis [102].

In summary, the actions of TNF $\alpha$ on LDL uptake in pHAECs are enhanced through the cell surface upregulation of LDLR, combined with the downregulation of SR-B1. Because SR-B1 is also a receptor for LDL, its downregulation promotes preferential binding and internalization through LDLR. Unlike SR-B1 which does not promote net LDL cholesterol accumulation in cells [102], LDLR is a potent inducer of LDL-derived cholesterol storage due to trafficking of its cargo to lysosomes. The finding that the inhibition of NF- $\mathrm{kB}$ or apoptosis mediators did not significantly affect TNF $\alpha$-induced Dil-LDL accumulation suggest that alternate signaling cascades are involved. 


\section{Materials and Methods}

\subsection{Materials}

The list of items used can be found under Supplemental Materials Table S1.

\subsection{Cell Culture and Incubations}

pHAECs, ATCC, lots 70001318, 63233442, and 64323512, passages 3-7, were used during the experiments, with similar results. The majority of experiments were performed using lot 70001318. Lot details are available on the ATCC website. The characteristics were routinely verified by criteria of cobblestone morphology at confluence and expression of the von Willenbrand factor. The cells were maintained in VBM with growth factor kit (VEGF) in the presence of $15 \%$ FBS, and antibiotic, antimycotic (100 units $/ \mathrm{mL}$ of penicillin, $100 \mu \mathrm{g} / \mathrm{mL}$ of streptomycin, and $0.25 \mu \mathrm{g} / \mathrm{mL}$ of amphotericin B. Under serum-free conditions, the cells were cultured in VBM, VEGF, with the latter antimicrobials and 0.1\% FAF-BSA. Incubations were at $37^{\circ} \mathrm{C}$, unless indicated otherwise. The experiments were best started with pHAECs confluent for 5 days or longer. Separate cells from individuals (2-36 years old) were used during the course of the experiments, with similar results. Incubations were $24 \pm 5 \mathrm{~h}$. For cell-associated studies at $37^{\circ} \mathrm{C}$, the cells were washed $3 \times$ with ice cold mHBSS. Imaging studies demonstrated that the vast majority of Dil-lipoproteins were within the cell under these conditions. For intracellular LDL levels, pHAECs were incubated on ice for $5 \mathrm{~min}$ with ice cold 400 units/mL sodium heparin in mHBSS, washed twice with the same buffer, then two more times with ice cold mHBSS, to remove surface LDL. In experiments using excess unlabeled lipoproteins, the volume represented $3 \%$ or less of the culture medium. Lipids were extracted as described below or the cells were fixed with $4 \%$ paraformaldehyde in PBS prior to microscopy.

\subsection{Lipoprotein Purification}

All procedures were performed between on ice to $4{ }^{\circ} \mathrm{C}$. Centrifugations and dialysis were performed at $4{ }^{\circ} \mathrm{C}$. Lipoproteins were isolated from freshly drawn human blood (BioIVT) anticoagulated with $\mathrm{Na}_{2}$ EDTA. Consenting and ethical standard procedures were conducted by the company. The blood was centrifuged at $4000 \times g$ for $30 \mathrm{~min}$ to obtain the plasma. To the plasma, butylated hydroxytoluene (BHT) in DMSO was added to $45 \mu \mathrm{M}$ $(0.01 \%)$. Then, sequential density ultracentrifugations [103] were performed to obtain $\mathrm{d}<1.006$ (VLDL), $\mathrm{d}=1.019-1.063$ (LDL), or $\mathrm{d}=1.12-1.21$ (HDL3) $\mathrm{g} / \mathrm{mL}$. Ultracentrifugations were done using type Ti70 rotor at 50,000 rpm for 20 (VLDL and LDL) or $48 \mathrm{~h}$ (HDL3). The lipoproteins were dialyzed through $\sim 4 \mathrm{kD}$ molecular weight cut-off membrane in 3 successions against 180 times dialysis buffer (DB): $10 \mathrm{mM}$ Tris- $\mathrm{HCl}, 150 \mathrm{mM}$ $\mathrm{NaCl}, 0.3 \mathrm{mM} \mathrm{Na}_{2}$ EDTA, $\mathrm{pH} 7.5$, with deionized water, in the dark, each lasting about $24 \mathrm{~h}$. After concentration using $3 \mathrm{kD}$ MWCO centrifugal filters, the LDL was filtered through $0.2 \mu \mathrm{m}$ membrane under sterile conditions. Lipoprotein contents were routinely verified by western blotting and coomassie staining. In addition, the cholesterol and cholesteryl ester contents were verified to be consistent with previous publications [104-106]. Lipoprotein concentrations represent the protein content throughout the manuscript.

\subsection{Cellular Cholesterol Determination}

The lipids were extracted into hexane: isopropanol (1:1) at room temperature for $3 \mathrm{~h}$, then the solvent was evaporated at room temperature using centrivap concentrator (Labconco). The extracted lipids were redissolved in isopropanol. To determine the unesterified cholesterol content, the lipids in isopropanol were mixed with 10 times volumes of cholesterol assay buffer (CAB): 0.1\% FAF-BSA, $2 \mathrm{mM}$ sodium taurocholate, $50 \mathrm{mM}$ Tris- $\mathrm{HCl}, \mathrm{pH} 7.5,0.3 \mathrm{mM} \mathrm{Na} 2 \mathrm{EDTA}, 5 \%$ isopropanol, and $250 \mathrm{mM}$ sucrose, with freshly added $0.5 \mathrm{U} / \mathrm{mL}$ horseradish peroxidase (HRP) and $0.02 \mathrm{U} / \mathrm{mL}$ cholesterol oxidase in the presence of 30-50 $\mu \mathrm{M}$ scopoletin [107] (excitation 360, emission 460). The CAB was kept at room temperature to ensure full solubilization of the lipids. This enzymatic approach is a modification of a previously published procedure [108]. Total cholesterol was determined 
as above, with the addition of $0.1 \mathrm{U} / \mathrm{mL}$ cholesteryl esterase. Readings were obtained after incubation at $37^{\circ} \mathrm{C}$ for $20 \mathrm{~min}$. Cholesteryl esters were determined by subtracting unesterified cholesterol from the total cholesterol. The residual cell matter after lipid extraction was lysed with $0.1 \mathrm{M} \mathrm{NaOH}, 0.1 \%$ SDS, for protein reading using BCA assay kit.

\subsection{Transwell Insert Experiments}

pHAEC (about $0.5 \times 10^{5}$ cells $/ \mathrm{mL}$ ) were seeded to $\sim 80 \%$ confluence on $3 \mu \mathrm{m}$ pore membrane inserts without coating and allowed to reach confluence for 5 days or longer, as judged from fluorescence imaging, and increasing resistance to $\left[{ }^{3} \mathrm{H}\right]$-inulin transport. The cell culture conditions were as indicated above. Arterial endothelial cells have been reported to form their own basement membrane with continued culture [109]. This approach represents a physiologically relevant extracellular matrix for the pHAECs. Cellular attachment to the inserts was achieved through limited trypsinization of pHAECs on plastic dishes. In brief, cells on plastic dishes were covered with trypsin-EDTA solution for $30 \mathrm{~s}$, then removed. Following incubation at $37^{\circ} \mathrm{C}$ for about $3 \mathrm{~min}$, a further trypsinization of the detached cells was quenched by resuspending the cells in complete culture medium as described in Section 2.2. The suspension was transferred to the inserts, containing the same medium on the basolateral side. Typically, when the cells reached full confluency, media on the apical side failed to leak to the basolateral compartment after overnight incubation at $37^{\circ} \mathrm{C}$. Details of the transport experiments are as described under Figure 11 and 12 legends. During the transport experiments, serum-free medium on the basolateral side was added such that the apical and basolateral heights were the same.

\section{6. ${ }^{3} \mathrm{H}$-Cholesteryl Ester $\left(\left[{ }^{3} \mathrm{H}\right] \mathrm{CE}\right)$ Generation}

First, $40 \mu \mathrm{Ci}$ of ${ }^{3} \mathrm{H}$-cholesterol in ethanol was added in $10 \mu \mathrm{L}$ aliquots to $40 \mathrm{~mL}$ of $0.2 \mu \mathrm{m}$ filtered human serum under sterile conditions. The mixture was incubated at $37^{\circ} \mathrm{C}$ for $48 \mathrm{~h}$ in the dark. ${ }^{3} \mathrm{H}$-cholesteryl esters and other lipids were extracted into chloroform: methanol [110]. After evaporation of the solvent, the residue was dissolved in a minimal volume of chloroform. Subsequently, ${ }^{3} \mathrm{H}$-cholesteryl esters were purified using serial bond elut columns with several hexane passages, as previously described [111].

\subsection{Western Blotting}

pHAECs were lysed with lysis buffer (150 mM NaCl, 2\% Triton X-100, 20 mM HEPES, $\mathrm{pH} 7.4,2 \%$ protease inhibitor and $2 \%$ phosphatase inhibitor by sonication at 2 setting (Fisher sonic dismembrator model 100) on ice for $10 \mathrm{~s}$. After centrifugation at 16,000 $\times \mathrm{g} /$ $10 \mathrm{~min}$ at $4{ }^{\circ} \mathrm{C}$, equal volume of loading buffer ( $8 \mathrm{M}$ urea, $2 \%$ SDS, $125 \mathrm{mM}$ Tris- $\mathrm{HCl}, \mathrm{pH}$ $7.0,5 \%$ glycerol, $10 \%$ beta-mercaptoethanol, $0.06 \%$ bromphenol blue) was mixed with the supernatant at room temperature. This was followed by electrophoresis, electrical transfer to PVDF membrane, and immunoblotting.

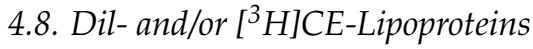

The generation of Dil-labeled lipoproteins was obtained essentially as previously described [112], with minor modifications. In brief, a mixture of about $2 \mathrm{mg}$ HDL3, LDL, or VLDL protein and $7 \mathrm{~mL}$ of human lipoprotein deficient serum was mixed with $\sim 1 \mathrm{mg}$ $\left[{ }^{3} \mathrm{H}\right] \mathrm{CE}$ and / or $0.5 \mathrm{mg}$ Dil in $10 \mu \mathrm{L}$ DMSO aliquots under sterile conditions. After covering with foil, the mixture was incubated at $37^{\circ} \mathrm{C}$ for $21 \mathrm{~h}$. The lipoproteins were repurified as described above, after adjusting to their respective densities with solid $\mathrm{KBr}$. Combined Dil, $\left[{ }^{3} \mathrm{H}\right] \mathrm{CE}-\mathrm{LDL}$ radioactivity was $8.1 \mathrm{dpm} / \mu \mathrm{g}$ protein.

\subsection{LDL Iodination with $\mathrm{Na}^{125} \mathrm{I}$}

About $2 \mathrm{mg}$ LDL protein in PBS and 10 iodination beads were incubated with $\mathrm{Na}^{125} \mathrm{I}$ for $10 \mathrm{~min}$ at room temperature in glass vials. The transformation was stopped with $50 \mathrm{mM}$ each of unlabeled sodium iodide and sulfite, and $100 \mu \mathrm{M}$ BHT in DMSO $(0.01 \%)$. The 
labeled LDL was washed with desalting columns, then passed through centrifugal filters, $3 \mathrm{kD}$ MWCO, against dialysis buffer.

\subsection{0. ${ }^{125}$ I-LDL Cell Surface Binding}

Confluent pHAECs on plastic dishes were cultured with 0 or $5 \mathrm{ng} / \mathrm{mL} \mathrm{TNF} \alpha$ in $15 \%$ serum for $48 \mathrm{~h}$. The treatment continued with serum-free medium in the continued presence of TNF $\alpha$ for $3 \mathrm{~h}$ to deplete surface-bound LDL. Subsequently, ${ }^{125} \mathrm{I}-\mathrm{LDL}$ was added to $15 \mu \mathrm{g} / \mathrm{mL}$ for $1 \mathrm{~h}$ at $37^{\circ} \mathrm{C}$. The cells were then washed two times with PBS at room temperature, then chilled on ice. Afterwards, serum-free medium at $4{ }^{\circ} \mathrm{C}$ with 0 (buffer) or $300 \mu \mathrm{g} / \mathrm{mL}$ LDL was added. Following additional incubation at $4{ }^{\circ} \mathrm{C}$ for $1 \mathrm{~h}$, the radioactivity released to the medium was taken as surface-releasable ${ }^{125}$ I-LDL.

\subsection{LDL Oxidation}

LDL was oxidized essentially as described [113]. Briefly, LDL was dialyzed against PBS at $4{ }^{\circ} \mathrm{C}$ to remove antioxidants, passed through $0.2 \mu \mathrm{m}$ filter, and incubated at $37^{\circ} \mathrm{C}$ for $22 \mathrm{~h}$ with $5 \mu \mathrm{M} \mathrm{CuSO}_{4}$ in PBS under sterile conditions. After adding BHT in DMSO $(0.005 \%)$ to $1 \mu \mathrm{M}$ and $\mathrm{Na}_{2}$ EDTA to $10 \mathrm{mM}$, the mixture was dialyzed against dialysis buffer (under Lipoprotein purification), and finally filtered through $0.2 \mu \mathrm{m}$ membrane under sterile conditions.

\subsection{TBARS Assay}

A 2-thiobarbituric assay to estimate the extent of LDL oxidation was determined essentially as previously described [114], with some modifications. oxLDL was mixed successively with 3 volumes of $0.67 \%$ 2-thiobarbituric acid in $50 \mathrm{mM} \mathrm{NaOH}$ and $20 \%$ trichloroacetic acid, each containing $1 \mathrm{mM} \mathrm{Na}{ }_{2}$ EDTA, respectively. After heating at $55^{\circ} \mathrm{C}$ for $1 \mathrm{~h}$, the mixture was centrifuged at $16,000 \times \mathrm{g} / 30 \mathrm{~s}$. Fluorescence $(530 \mathrm{~nm}$ excitation, $590 \mathrm{~nm}$ emission) reading in the supernatant was determined. Malonaldehyde bis-(dimethyl acetal) was used as a malondialdehyde (MDA) precursor for determining malondialdehyde standards. Care should be taken when performing this procedure, as volatile products are generated at $100{ }^{\circ} \mathrm{C}$. Standards up to $5 \mathrm{nmol} / \mu \mathrm{L}$ were used. oxLDL was measured at $54 \mathrm{nmol}$ MDA equivalents/mg protein.

\subsection{Depletion of apoE from Dil-Lipoproteins}

Normal mouse IgG agarose or apoE3 agarose beads were washed $4 \times$ with dialysis buffer under sterile conditions. Subsequently, Dil-HDL3 or Dil-LDL was added to the beads in dialysis buffer. Following $24 \mathrm{~h}$ incubation at $4{ }^{\circ} \mathrm{C}$, the unbound lipoproteins were sterile filtered through $0.2 \mu \mathrm{m}$ membranes.

\subsection{Cell Surface Biotinylation}

Serum media from confluent pHAECs were replaced with $400 \mathrm{U} / \mathrm{mL}$ sodium heparin in mHBSS on ice for $5 \mathrm{~min}$, washed $2 \times$ with the the same buffer, then $1 \times$ with ice cold mHBSS. After $1 \times$ wash with ice cold $1 \times$ PBS, the cells were treated with EZ Link Sulfo NHS Biotin in $1 \times$ PBS for $30 \mathrm{~min}$ at $4{ }^{\circ} \mathrm{C}$. Unreacted biotin reagent was quenched with $100 \mathrm{mM}$ glycine in PBS at $4{ }^{\circ} \mathrm{C}$ for $5 \mathrm{~min}$. Following $1 \times$ wash with ice cold mHBSS, the cells were lysed on the plates with lysis buffer as indicated above under Western blotting on ice for $30 \mathrm{~min}$, followed by sonication at 2 setting for $10 \mathrm{~s}$ on ice. Aliquots of the supernatant was mixed with 1 volume of $2 \times$ urea loading buffer without heating. The rest of the supernatant was mixed with strepavidin mag sepharose (pre-washed $2 \times$ with incubation buffer: $1 \%$ BSA, $0.1 \%$ NaN3, $0.1 \%$ Triton X-100). After $10 \times$ dilution with the incubation buffer containing $0.5 \%$ each of protease inhibitor and phosphate inhibitor cocktails, the suspension was swirled for $12 \mathrm{~h}$ at $4{ }^{\circ} \mathrm{C}$. The beads were washed $4 \times$ with precipitation buffer, then mHBSS at $4{ }^{\circ} \mathrm{C}$. After $1 \times$ urea loading buffer (1:1 volume of lysis buffer and $2 \times$ urea loading buffer), with $1 \%$ protease and phosphatase inhibitors, respectively, the samples were heated at $95^{\circ} \mathrm{C}$ for $5 \mathrm{~min}$ to solubilize the bound biotinylated proteins. 


\subsection{Dextran-Mn Separation of Intact and Non-Intact ${ }^{125} I-L D L$}

Intact ${ }^{125} \mathrm{I}$-LDL was separated from non-intact LDL using dextran sulfate, $\mathrm{Mn}^{2+}$ procedure essentially as previously described [115]. To the BL medium, $\mathrm{d}<1.21 \mathrm{~g} / \mathrm{mL}$ FBS was added to $15 \%$ to produce a visible precipitate, mixed, then dextran sulfate and $\mathrm{MnCl}$ were added to $65 \mathrm{mg} / \mathrm{mL}$ and $0.2 \mathrm{M}$, respectively. After incubation for $20 \mathrm{~min}$ at room temperature, the mixtures were centrifuged at $5000 \times \mathrm{g} / 5 \mathrm{~min}$ at $4{ }^{\circ} \mathrm{C}$. The pellet was redissolved with $20 \mathrm{mg} / \mathrm{mL}$ dextran sulfate before scintillation counting.

\subsection{Immunofluorescence}

Confluent pHAECs in serum medium were incubated with 0 or $100 \mathrm{ng} / \mathrm{mL}$ TNF $\alpha$ for $24 \mathrm{~h}$. Subsequently, the media were replaced with serum-free medium containing $10 \mu \mathrm{g} / \mathrm{mL}$ normal goat IgG or LDLR Ab (R\&D Systems) in the continued presence of 0 or $100 \mathrm{ng} / \mathrm{mL} \mathrm{TNF} \alpha$ for $0,5,30$, or $120 \mathrm{~min}$ at $37^{\circ} \mathrm{C}$. Afterwards, the cells were chilled on ice and further incubated at $4{ }^{\circ} \mathrm{C}$ for $1 \mathrm{~h}$. Then the cells were washed $2 \times$ with ice-cold mHBSS, fixed with ice-cold methanol at $-20{ }^{\circ} \mathrm{C}$ for $10 \mathrm{~min}$, washed once with mHBSS at room temperature, then blocked with $50 \%$ human serum in mHBSS, $0.1 \%$ sodium azide (blocking buffer) for $1 \mathrm{~h}$ at room temperature. Afterwards, it was replaced with $4 \mu \mathrm{g} / \mathrm{mL}$ red antigoat antibody in blocking buffer. Following $30 \mathrm{~min}$ incubation at room temperature, the medium was replaced with mHBSS, washed $3 \times$ with blocking buffer (10 min each at room temperature), fixed with $4 \%$ paraformaldehyde in PBS, followed by fluorescence microscopy.

\subsection{Fluorescence Microscopy}

Fluorescence microscopy was performed using Keyence phase-contrast fluorescence microscope. Images were analyzed using CellProfiler [116]. Confocal microscopy was performed using glass bottom dishes (Cellvis).

\subsection{Statistical Analysis}

Data are reported as averages \pm standard deviation. $n=$ number of independent experiments performed on separate days. Most experiments were performed with an average of 3 or greater replicates. Analysis of variance, followed by Tukey post-hoc testing was done by using statpages.info website.

Supplementary Materials: The following are available online at https:/ /www.mdpi.com/article/10 $.3390 / \mathrm{ijms} 22126236 / \mathrm{s} 1$.

Funding: This work was supported through institutional grants: Meharry Clinical and Translation Research Center (MeTRC) 5U54MD007593-09, RCMI 5U54MD007586-33, as well as SC1HL101431. Confocal microscopy core was supported through NIH grants MHD007586 and S10RR025497.

Institutional Review Board Statement: Not applicable.

Informed Consent Statement: Not applicable.

Acknowledgments: The author thanks the Meharry core facility staff for assistance in the using the equipment.

Conflicts of Interest: The authors declare no conflict of interest. The funders had no role in the design of the study; in the collection, analyses, or interpretation of data; in the writing of the manuscript, or in the decision to publish the results. 


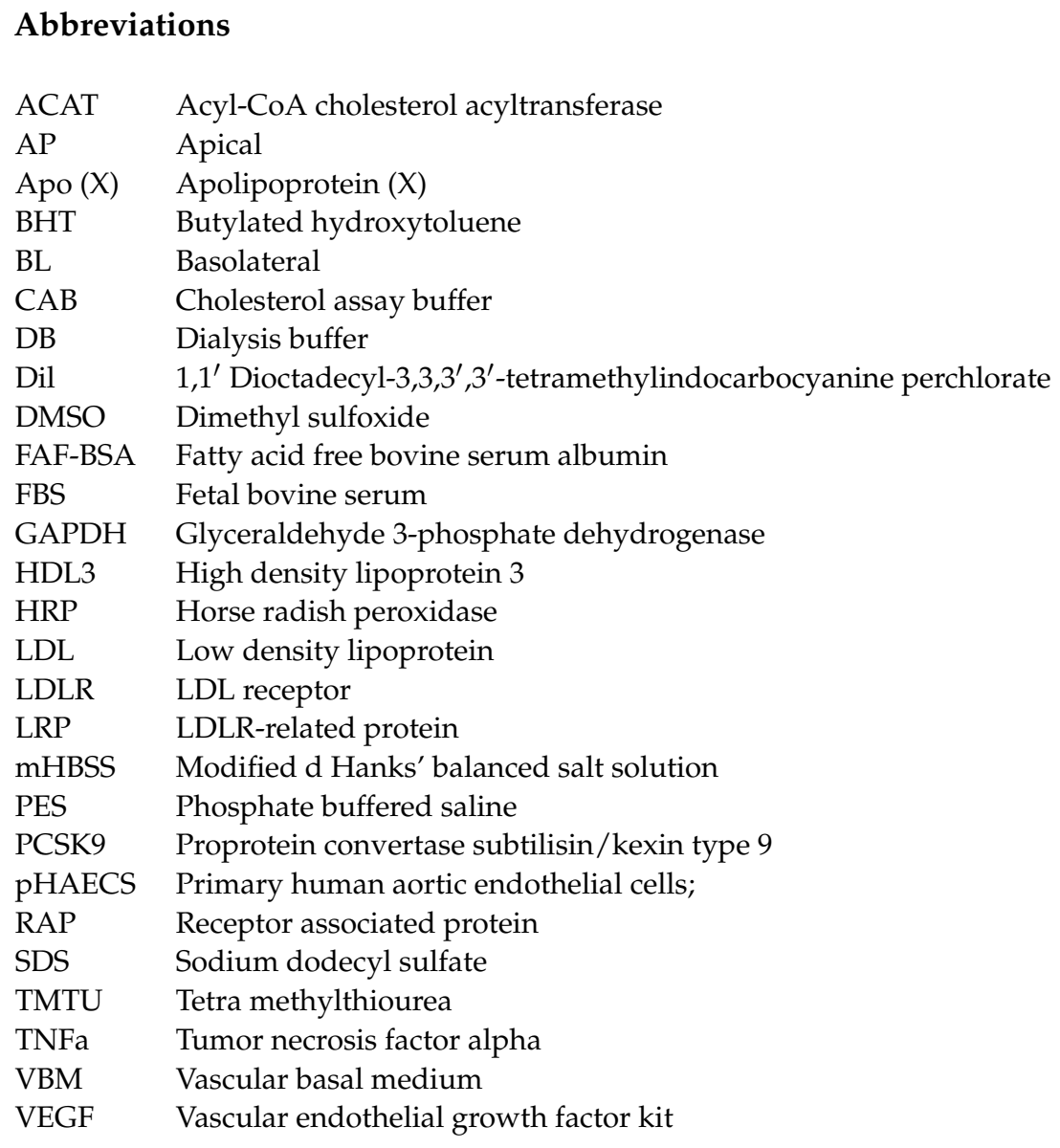

\section{References}

1. Carswell, E.A.; Old, L.J.; Kassel, R.L.; Green, S.; Fiore, N.; Williamson, B. An endotoxin-induced serum factor that causes necrosis of tumors. Proc. Natl. Acad. Sci. USA 1975, 72,3666-3670. [CrossRef]

2. Balkwill, F. Tumour necrosis factor and cancer. Nat. Rev. Cancer 2009, 9, 361-371. [CrossRef]

3. Holbrook, J.; Lara-Reyna, S.; Jarosz-Griffiths, H.; McDermott, M. Tumour necrosis factor signalling in health and disease. F1000Research 2019, 8. [CrossRef] [PubMed]

4. Mercogliano, M.F.; Bruni, S.; Elizalde, P.V.; Schillaci, R. Tumor Necrosis Factor alpha Blockade: An Opportunity to Tackle Breast Cancer. Front. Oncol. 2020, 10, 584. [CrossRef] [PubMed]

5. Kriegler, M.; Perez, C.; DeFay, K.; Albert, I.; Lu, S.D. A novel form of TNF/cachectin is a cell surface cytotoxic transmembrane protein: Ramifications for the complex physiology of TNF. Cell 1988, 53, 45-53. [CrossRef]

6. Jue, D.M.; Sherry, B.; Luedke, C.; Manogue, K.R.; Cerami, A. Processing of newly synthesized cachectin/tumor necrosis factor in endotoxin-stimulated macrophages. Biochemistry 1990, 29, 8371-8377. [CrossRef] [PubMed]

7. $\quad$ Black, R.A.; Rauch, C.T.; Kozlosky, C.J.; Peschon, J.J.; Slack, J.L.; Wolfson, M.F.; Castner, B.J.; Stocking, K.L.; Reddy, P.; Srinivasan, S.; et al. A metalloproteinase disintegrin that releases tumour-necrosis factor-alpha from cells. Nature 1997, 385, 729-733. [CrossRef] [PubMed]

8. Sedger, L.M.; McDermott, M.F. TNF and TNF-receptors: From mediators of cell death and inflammation to therapeutic giants past, present and future. Cytokine Growth Factor Rev. 2014, 25, 453-472. [CrossRef]

9. Hiscott, J.; Marois, J.; Garoufalis, J.; D’Addario, M.; Roulston, A.; Kwan, I.; Pepin, N.; Lacoste, J.; Nguyen, H.; Bensi, G.; et al. Characterization of a functional NF-kappa B site in the human interleukin 1 beta promoter: Evidence for a positive autoregulatory loop. Mol. Cell. Biol. 1993, 13, 6231-6240. [CrossRef] [PubMed]

10. Paliogianni, F.; Raptis, A.; Ahuja, S.S.; Najjar, S.M.; Boumpas, D.T. Negative transcriptional regulation of human interleukin 2 (IL-2) gene by glucocorticoids through interference with nuclear transcription factors AP-1 and NF-AT. J. Clin. Investig. 1993, 91, 1481-1489. [CrossRef] [PubMed]

11. Laster, S.M.; Wood, J.G.; Gooding, L.R. Tumor necrosis factor can induce both apoptic and necrotic forms of cell lysis. J. Immunol. 1988, 141, 2629-2634.

12. Sugarman, B.J.; Aggarwal, B.B.; Hass, P.E.; Figari, I.S.; Palladino, M.A., Jr.; Shepard, H.M. Recombinant human tumor necrosis factor-alpha: Effects on proliferation of normal and transformed cells in vitro. Science 1985, 230, 943-945. [CrossRef] 
13. Frater-Schroder, M.; Risau, W.; Hallmann, R.; Gautschi, P.; Bohlen, P. Tumor necrosis factor type alpha, a potent inhibitor of endothelial cell growth in vitro, is angiogenic in vivo. Proc. Natl. Acad. Sci. USA 1987, 84, 5277-5281. [CrossRef]

14. Verheij, M.; Bose, R.; Lin, X.H.; Yao, B.; Jarvis, W.D.; Grant, S.; Birrer, M.J.; Szabo, E.; Zon, L.I.; Kyriakis, J.M.; et al. Requirement for ceramide-initiated SAPK/JNK signalling in stress-induced apoptosis. Nature 1996, 380, 75-79. [CrossRef]

15. Sluss, H.K.; Barrett, T.; Derijard, B.; Davis, R.J. Signal transduction by tumor necrosis factor mediated by JNK protein kinases. Mol. Cell. Biol. 1994, 14, 8376-8384. [CrossRef] [PubMed]

16. Aoki, H.; Kang, P.M.; Hampe, J.; Yoshimura, K.; Noma, T.; Matsuzaki, M.; Izumo, S. Direct activation of mitochondrial apoptosis machinery by c-Jun N-terminal kinase in adult cardiac myocytes. J. Biol. Chem. 2002, 277, 10244-10250. [CrossRef]

17. Scheurich, P.; Thoma, B.; Ucer, U.; Pfizenmaier, K. Immunoregulatory activity of recombinant human tumor necrosis factor (TNF)-alpha: Induction of TNF receptors on human T cells and TNF-alpha-mediated enhancement of T cell responses. J. Immunol. $1987,138,1786-1790$.

18. Vilcek, J.; Palombella, V.J.; Henriksen-DeStefano, D.; Swenson, C.; Feinman, R.; Hirai, M.; Tsujimoto, M. Fibroblast growth enhancing activity of tumor necrosis factor and its relationship to other polypeptide growth factors. J. Exp. Med. 1986, 163, 632-643. [CrossRef]

19. Bruggeman, L.A.; Drawz, P.E.; Kahoud, N.; Lin, K.; Barisoni, L.; Nelson, P.J. TNFR2 interposes the proliferative and NF-kappaBmediated inflammatory response by podocytes to TNF-alpha. Lab. Investig. 2011, 91, 413-425. [CrossRef]

20. Ligresti, G.; Aplin, A.C.; Zorzi, P.; Morishita, A.; Nicosia, R.F. Macrophage-derived tumor necrosis factor-alpha is an early component of the molecular cascade leading to angiogenesis in response to aortic injury. Arterioscler. Thromb. Vasc. Biol. 2011, 31, 1151-1159. [CrossRef]

21. Jelinek, D.F.; Lipsky, P.E. Enhancement of human B cell proliferation and differentiation by tumor necrosis factor-alpha and interleukin 1. J. Immunol. 1987, 139, 2970-2976.

22. Barath, P.; Fishbein, M.C.; Cao, J.; Berenson, J.; Helfant, R.H.; Forrester, J.S. Detection and localization of tumor necrosis factor in human atheroma. Am. J. Cardiol. 1990, 65, 297-302. [CrossRef]

23. Barath, P.; Fishbein, M.C.; Cao, J.; Berenson, J.; Helfant, R.H.; Forrester, J.S. Tumor necrosis factor gene expression in human vascular intimal smooth muscle cells detected by in situ hybridization. Am. J. Pathol. 1990, 137, 503-509.

24. Zhang, X.; Bishawi, M.; Zhang, G.; Prasad, V.; Salmon, E.; Breithaupt, J.J.; Zhang, Q.; Truskey, G.A. Modeling early stage atherosclerosis in a primary human vascular microphysiological system. Nat. Commun. 2020, 11, 5426. [CrossRef]

25. Zeiher, A.M.; Fisslthaler, B.; Schray-Utz, B.; Busse, R. Nitric oxide modulates the expression of monocyte chemoattractant protein 1 in cultured human endothelial cells. Circ. Res. 1995, 76, 980-986. [CrossRef] [PubMed]

26. Carr, M.W.; Roth, S.J.; Luther, E.; Rose, S.S.; Springer, T.A. Monocyte chemoattractant protein 1 acts as a T-lymphocyte chemoattractant. Proc. Natl. Acad. Sci. USA 1994, 91, 3652-3656. [CrossRef] [PubMed]

27. Deshmane, S.L.; Kremlev, S.; Amini, S.; Sawaya, B.E. Monocyte chemoattractant protein-1 (MCP-1): An overview. J. Interferon Cytokine Res. 2009, 29, 313-326. [CrossRef]

28. Yuan, S.; Carter, P.; Bruzelius, M.; Vithayathil, M.; Kar, S.; Mason, A.M.; Lin, A.; Burgess, S.; Larsson, S.C. Effects of tumour necrosis factor on cardiovascular disease and cancer: A two-sample Mendelian randomization study. EBioMedicine 2020, 59, 102956. [CrossRef]

29. Rus, H.G.; Niculescu, F.; Vlaicu, R. Tumor necrosis factor-alpha in human arterial wall with atherosclerosis. Atherosclerosis 1991, 89, 247-254. [CrossRef]

30. Paolisso, G.; Rizzo, M.R.; Mazziotti, G.; Tagliamonte, M.R.; Gambardella, A.; Rotondi, M.; Carella, C.; Giugliano, D.; Varricchio, M.; D'Onofrio, F. Advancing age and insulin resistance: Role of plasma tumor necrosis factor-alpha. Am. J. Physiol. 1998, 275, E294-E299. [CrossRef]

31. Byl, B.; Roucloux, I.; Crusiaux, A.; Dupont, E.; Deviere, J. Tumor necrosis factor alpha and interleukin 6 plasma levels in infected cirrhotic patients. Gastroenterology 1993, 104, 1492-1497. [CrossRef]

32. Nagashima, S.; Mendes, M.C.; Camargo Martins, A.P.; Borges, N.H.; Godoy, T.M.; Miggiolaro, A.; da Silva Deziderio, F.; MachadoSouza, C.; de Noronha, L. Endothelial Dysfunction and Thrombosis in Patients With COVID-19-Brief Report. Arterioscler. Thromb. Vasc. Biol. 2020, 40, 2404-2407. [CrossRef]

33. Liu, Y.N.; Peng, Y.L.; Liu, L.; Wu, T.Y.; Zhang, Y.; Lian, Y.J.; Yang, Y.Y.; Kelley, K.W.; Jiang, C.L.; Wang, Y.X. TNFalpha mediates stress-induced depression by upregulating indoleamine 2,3-dioxygenase in a mouse model of unpredictable chronic mild stress. Eur. Cytokine Netw. 2015, 26, 15-25. [CrossRef]

34. Schreyer, S.A.; Peschon, J.J.; LeBoeuf, R.C. Accelerated atherosclerosis in mice lacking tumor necrosis factor receptor p55. J. Biol. Chem. 1996, 271, 26174-26178. [CrossRef]

35. Schreyer, S.A.; Vick, C.M.; LeBoeuf, R.C. Loss of lymphotoxin-alpha but not tumor necrosis factor-alpha reduces atherosclerosis in mice. J. Biol. Chem. 2002, 277, 12364-12368. [CrossRef]

36. Branen, L.; Hovgaard, L.; Nitulescu, M.; Bengtsson, E.; Nilsson, J.; Jovinge, S. Inhibition of tumor necrosis factor-alpha reduces atherosclerosis in apolipoprotein E knockout mice. Arterioscler. Thromb. Vasc. Biol. 2004, 24, 2137-2142. [CrossRef]

37. Zhang, L.; Peppel, K.; Sivashanmugam, P.; Orman, E.S.; Brian, L.; Exum, S.T.; Freedman, N.J. Expression of tumor necrosis factor receptor-1 in arterial wall cells promotes atherosclerosis. Arterioscler. Thromb. Vasc. Biol. 2007, 27, 1087-1094. [CrossRef] 
38. Xanthoulea, S.; Thelen, M.; Pottgens, C.; Gijbels, M.J.; Lutgens, E.; de Winther, M.P. Absence of p55 TNF receptor reduces atherosclerosis, but has no major effect on angiotensin II induced aneurysms in LDL receptor deficient mice. PLOS ONE 2009, 4, e6113. [CrossRef]

39. Blessing, E.; Bea, F.; Kuo, C.C.; Campbell, L.A.; Chesebro, B.; Rosenfeld, M.E. Lesion progression and plaque composition are not altered in older apoE-/- mice lacking tumor necrosis factor-alpha receptor p55. Atherosclerosis 2004, 176, 227-232. [CrossRef] [PubMed]

40. Chandrasekharan, U.M.; Mavrakis, L.; Bonfield, T.L.; Smith, J.D.; DiCorleto, P.E. Decreased atherosclerosis in mice deficient in tumor necrosis factor-alpha receptor-II (p75). Arterioscler. Thromb. Vasc. Biol. 2007, 27, e16-e17. [CrossRef]

41. Canault, M.; Peiretti, F.; Mueller, C.; Kopp, F.; Morange, P.; Rihs, S.; Portugal, H.; Juhan-Vague, I.; Nalbone, G. Exclusive expression of transmembrane TNF-alpha in mice reduces the inflammatory response in early lipid lesions of aortic sinus. Atherosclerosis 2004, 172, 211-218. [CrossRef]

42. Ohta, H.; Wada, H.; Niwa, T.; Kirii, H.; Iwamoto, N.; Fujii, H.; Saito, K.; Sekikawa, K.; Seishima, M. Disruption of tumor necrosis factor-alpha gene diminishes the development of atherosclerosis in ApoE-deficient mice. Atherosclerosis 2005, 180, 11-17. [CrossRef] [PubMed]

43. Boesten, L.S.; Zadelaar, A.S.; van Nieuwkoop, A.; Gijbels, M.J.; de Winther, M.P.; Havekes, L.M.; van Vlijmen, B.J. Tumor necrosis factor-alpha promotes atherosclerotic lesion progression in APOE*3-Leiden transgenic mice. Cardiovasc. Res. 2005, 66, 179-185. [CrossRef] [PubMed]

44. Oberoi, R.; Vlacil, A.K.; Schuett, J.; Schosser, F.; Schuett, H.; Tietge, U.J.F.; Schieffer, B.; Grote, K. Anti-tumor necrosis factor-alpha therapy increases plaque burden in a mouse model of experimental atherosclerosis. Atherosclerosis 2018, 277, 80-89. [CrossRef]

45. Ross, R.; Wight, T.N.; Strandness, E.; Thiele, B. Human atherosclerosis. I. Cell constitution and characteristics of advanced lesions of the superficial femoral artery. Am. J. Pathol. 1984, 114, 79-93.

46. Hoff, H.F.; Morton, R.E. Lipoproteins containing apo B extracted from human aortas. Structure and function. Ann. N. Y. Acad. Sci. 1985, 454, 183-194. [CrossRef]

47. Mahley, R.W.; Innerarity, T.L.; Weisgraber, K.H.; Fry, D.L. Canine hyperlipoproteinemia and atherosclerosis. Accumulation of lipid by aortic medial cells in vivo and in vitro. Am. J. Pathol. 1977, 87, 205-226. [PubMed]

48. Vlodavsky, I.; Fielding, P.E.; Fielding, C.J.; Gospodarowicz, D. Role of contact inhibition in the regulation of receptor-mediated uptake of low density lipoprotein in cultured vascular endothelial cells. Proc. Natl. Acad. Sci. USA 1978, 75, 356-360. [CrossRef]

49. Kzhyshkowska, J.; Neyen, C.; Gordon, S. Role of macrophage scavenger receptors in atherosclerosis. Immunobiology 2012, 217, 492-502. [CrossRef] [PubMed]

50. Li, H.; Freeman, M.W.; Libby, P. Regulation of smooth muscle cell scavenger receptor expression in vivo by atherogenic diets and in vitro by cytokines. J. Clin. Investig. 1995, 95, 122-133. [CrossRef]

51. Poole, J.C.; Florey, H.W. Changes in the endothelium of the aorta and the behaviour of macrophages in experimental atheroma of rabbits. J. Pathol. Bacteriol. 1958, 75, 245-251. [CrossRef]

52. Simionescu, M. Implications of early structural-functional changes in the endothelium for vascular disease. Arterioscler. Thromb. Vasc. Biol. 2007, 27, 266-274. [CrossRef]

53. Joris, I.; Zand, T.; Nunnari, J.J.; Krolikowski, F.J.; Majno, G. Studies on the pathogenesis of atherosclerosis. I. Adhesion and emigration of mononuclear cells in the aorta of hypercholesterolemic rats. Am. J. Pathol. 1983, 113, 341-358.

54. Kattoor, A.J.; Goel, A.; Mehta, J.L. LOX-1: Regulation, Signaling and Its Role in Atherosclerosis. Antioxidants (Basel) 2019,8 , 218. [CrossRef]

55. Zheng, J.; Lu, C. Oxidized LDL Causes Endothelial Apoptosis by Inhibiting Mitochondrial Fusion and Mitochondria Autophagy. Front Cell Dev Biol 2020, 8, 600950. [CrossRef]

56. Mollace, V.; Gliozzi, M.; Musolino, V.; Carresi, C.; Muscoli, S.; Mollace, R.; Tavernese, A.; Gratteri, S.; Palma, E.; Morabito, C.; et al. Oxidized LDL attenuates protective autophagy and induces apoptotic cell death of endothelial cells: Role of oxidative stress and LOX-1 receptor expression. Int. J. Cardiol. 2015, 184, 152-158. [CrossRef]

57. Zhang, Y.; Vittinghoff, E.; Pletcher, M.J.; Allen, N.B.; Zeki Al Hazzouri, A.; Yaffe, K.; Balte, P.P.; Alonso, A.; Newman, A.B.; Ives, D.G.; et al. Associations of Blood Pressure and Cholesterol Levels During Young Adulthood With Later Cardiovascular Events. J. Am. Coll. Cardiol. 2019, 74, 330-341. [CrossRef]

58. Boren, J.; Chapman, M.J.; Krauss, R.M.; Packard, C.J.; Bentzon, J.F.; Binder, C.J.; Daemen, M.J.; Demer, L.L.; Hegele, R.A.; Nicholls, S.J.; et al. Low-density lipoproteins cause atherosclerotic cardiovascular disease: Pathophysiological, genetic, and therapeutic insights: A consensus statement from the European Atherosclerosis Society Consensus Panel. Eur. Heart J. 2020, 41, $2313-2330$. [CrossRef]

59. Holthenrich, A.; Gerke, V. Regulation of von-Willebrand Factor Secretion from Endothelial Cells by the Annexin A2-S100A10 Complex. Int. J. Mol. Sci. 2018, 19, 1752. [CrossRef]

60. Lei, L.; Xiong, Y.; Chen, J.; Yang, J.B.; Wang, Y.; Yang, X.Y.; Chang, C.C.; Song, B.L.; Chang, T.Y.; Li, B.L. TNF-alpha stimulates the ACAT1 expression in differentiating monocytes to promote the CE-laden cell formation. J. Lipid Res. 2009, 50, $1057-1067$. [CrossRef]

61. An, S.; Jang, Y.S.; Park, J.S.; Kwon, B.M.; Paik, Y.K.; Jeong, T.S. Inhibition of acyl-coenzyme A:cholesterol acyltransferase stimulates cholesterol efflux from macrophages and stimulates farnesoid X receptor in hepatocytes. Exp. Mol. Med. 2008, 40, 407-417. [CrossRef] 
62. Satriano, J.A.; Shuldiner, M.; Hora, K.; Xing, Y.; Shan, Z.; Schlondorff, D. Oxygen radicals as second messengers for expression of the monocyte chemoattractant protein, JE/MCP-1, and the monocyte colony-stimulating factor, CSF-1, in response to tumor necrosis factor-alpha and immunoglobulin G. Evidence for involvement of reduced nicotinamide adenine dinucleotide phosphate (NADPH)-dependent oxidase. J. Clin. Investig. 1993, 92, 1564-1571. [CrossRef]

63. Ding, A.H.; Nathan, C.F.; Stuehr, D.J. Release of reactive nitrogen intermediates and reactive oxygen intermediates from mouse peritoneal macrophages. Comparison of activating cytokines and evidence for independent production. J. Immunol. 1988, 141, 2407-2412. [PubMed]

64. Trinh, M.N.; Brown, M.S.; Goldstein, J.L.; Han, J.; Vale, G.; McDonald, J.G.; Seemann, J.; Mendell, J.T.; Lu, F. Last step in the path of LDL cholesterol from lysosome to plasma membrane to ER is governed by phosphatidylserine. Proc. Natl. Acad. Sci. USA 2020, 117, 18521-18529. [CrossRef]

65. Hevonoja, T.; Pentikainen, M.O.; Hyvonen, M.T.; Kovanen, P.T.; Ala-Korpela, M. Structure of low density lipoprotein (LDL) particles: Basis for understanding molecular changes in modified LDL. Biochim. Biophys. Acta 2000, 1488, 189-210. [CrossRef]

66. Mendivil, C.O.; Rimm, E.B.; Furtado, J.; Sacks, F.M. Apolipoprotein E in VLDL and LDL with apolipoprotein C-III is associated with a lower risk of coronary heart disease. J. Am. Heart Assoc. 2013, 2, e000130. [CrossRef]

67. Holtzman, D.M.; Herz, J.; Bu, G. Apolipoprotein E and apolipoprotein E receptors: Normal biology and roles in Alzheimer disease. Cold Spring Harb. Perspect. Med. 2012, 2, a006312. [CrossRef]

68. Zhao, N.; Liu, C.C.; Qiao, W.; Bu, G. Apolipoprotein E, Receptors, and Modulation of Alzheimer's Disease. Biol. Psychiatry 2018, 83, 347-357. [CrossRef]

69. Shan, L.; Pang, L.; Zhang, R.; Murgolo, N.J.; Lan, H.; Hedrick, J.A. PCSK9 binds to multiple receptors and can be functionally inhibited by an EGF-A peptide. Biochem. Biophys. Res. Commun. 2008, 375, 69-73. [CrossRef]

70. Poirier, S.; Mayer, G.; Benjannet, S.; Bergeron, E.; Marcinkiewicz, J.; Nassoury, N.; Mayer, H.; Nimpf, J.; Prat, A.; Seidah, N.G. The proprotein convertase PCSK9 induces the degradation of low density lipoprotein receptor (LDLR) and its closest family members VLDLR and ApoER2. J. Biol. Chem. 2008, 283, 2363-2372. [CrossRef]

71. Canuel, M.; Sun, X.; Asselin, M.C.; Paramithiotis, E.; Prat, A.; Seidah, N.G. Proprotein convertase subtilisin/kexin type 9 (PCSK9) can mediate degradation of the low density lipoprotein receptor-related protein 1 (LRP-1). PLoS ONE 2013, 8, e64145. [CrossRef]

72. Ruiz, J.; Kouiavskaia, D.; Migliorini, M.; Robinson, S.; Saenko, E.L.; Gorlatova, N.; Li, D.; Lawrence, D.; Hyman, B.T.; Weisgraber, K.H.; et al. The apoE isoform binding properties of the VLDL receptor reveal marked differences from LRP and the LDL receptor. J. Lipid Res. 2005, 46, 1721-1731. [CrossRef]

73. Kraemer, F.B.; Shen, W.J.; Patel, S.; Osuga, J.; Ishibashi, S.; Azhar, S. The LDL receptor is not necessary for acute adrenal steroidogenesis in mouse adrenocortical cells. Am. J. Physiol. Endocrinol. Metab. 2007, 292, E408-E412. [CrossRef]

74. He, P.; Gelissen, I.C.; Ammit, A.J. Regulation of ATP binding cassette transporter A1 (ABCA1) expression: Cholesterol-dependent and - independent signaling pathways with relevance to inflammatory lung disease. Respir. Res. 2020, 21, 250. [CrossRef]

75. Gerbod-Giannone, M.C.; Li, Y.; Holleboom, A.; Han, S.; Hsu, L.C.; Tabas, I.; Tall, A.R. TNFalpha induces ABCA1 through NF-kappaB in macrophages and in phagocytes ingesting apoptotic cells. Proc. Natl. Acad. Sci. USA 2006, 103, 3112-3117. [CrossRef]

76. Khovidhunkit, W.; Moser, A.H.; Shigenaga, J.K.; Grunfeld, C.; Feingold, K.R. Regulation of scavenger receptor class B type I in hamster liver and Hep3B cells by endotoxin and cytokines. J. Lipid Res. 2001, 42, 1636-1644. [CrossRef]

77. Simon, L.; Campos, A.; Leyton, L.; Quest, A.F.G. Caveolin-1 function at the plasma membrane and in intracellular compartments in cancer. Cancer Metastasis Rev. 2020, 39, 435-453. [CrossRef]

78. Hubert, M.; Larsson, E.; Vegesna, N.V.G.; Ahnlund, M.; Johansson, A.I.; Moodie, L.W.; Lundmark, R. Lipid accumulation controls the balance between surface connection and scission of caveolae. Elife 2020, 9. [CrossRef]

79. Ogier, J.M.; Nayagam, B.A.; Lockhart, P.J. ASK1 inhibition: A therapeutic strategy with multi-system benefits. J. Mol. Med. (Berl.) 2020, 98, 335-348. [CrossRef]

80. Xia, X.; Xu, Q.; Liu, M.; Chen, X.; Liu, X.; He, J.; Hu, T.; Yu, C.; Huang, H.; Liu, S.; et al. Deubiquitination of CD36 by UCHL1 promotes foam cell formation. Cell Death Dis. 2020, 11, 636. [CrossRef]

81. Ruuth, M.; Nguyen, S.D.; Vihervaara, T.; Hilvo, M.; Laajala, T.D.; Kondadi, P.K.; Gistera, A.; Lahteenmaki, H.; Kittila, T.; Huusko, J.; et al. Susceptibility of low-density lipoprotein particles to aggregate depends on particle lipidome, is modifiable, and associates with future cardiovascular deaths. Eur. Heart J. 2018, 39, 2562-2573. [CrossRef]

82. Hurt, E.; Camejo, G. Effect of arterial proteoglycans on the interaction of LDL with human monocyte-derived macrophages. Atherosclerosis 1987, 67, 115-126. [CrossRef]

83. Salisbury, B.G.; Falcone, D.J.; Minick, C.R. Insoluble low-density lipoprotein-proteoglycan complexes enhance cholesteryl ester accumulation in macrophages. Am. J. Pathol. 1985, 120, 6-11.

84. Hurt, E.; Bondjers, G.; Camejo, G. Interaction of LDL with human arterial proteoglycans stimulates its uptake by human monocyte-derived macrophages. J. Lipid Res. 1990, 31, 443-454. [CrossRef]

85. Puig, N.; Montolio, L.; Camps-Renom, P.; Navarra, L.; Jimenez-Altayo, F.; Jimenez-Xarrie, E.; Sanchez-Quesada, J.L.; Benitez, S. Electronegative LDL Promotes Inflammation and Triglyceride Accumulation in Macrophages. Cells 2020, 9, 583. [CrossRef]

86. Malhotra, P.; Gill, R.K.; Saksena, S.; Alrefai, W.A. Disturbances in Cholesterol Homeostasis and Non-alcoholic Fatty Liver Diseases. Front. Med. (Lausanne) 2020, 7, 467. [CrossRef] 
87. LaRosa, J.C.; Grundy, S.M.; Waters, D.D.; Shear, C.; Barter, P.; Fruchart, J.C.; Gotto, A.M.; Greten, H.; Kastelein, J.J.; Shepherd, J.; et al. Intensive lipid lowering with atorvastatin in patients with stable coronary disease. N. Engl. J. Med. 2005, 352, 1425-1435. [CrossRef]

88. Silverstein, R.L. PCSK9 (Proprotein Convertase Subtilisin/Kexin 9) Goes "DAMP". Circulation 2021, 143, 62-64. [CrossRef]

89. Adorni, M.P.; Zimetti, F.; Lupo, M.G.; Ruscica, M.; Ferri, N. Naturally Occurring PCSK9 Inhibitors. Nutrients 2020, 12, 1440. [CrossRef]

90. Qi, Z.; Hu, L.; Zhang, J.; Yang, W.; Liu, X.; Jia, D.; Yao, Z.; Chang, L.; Pan, G.; Zhong, H.; et al. PCSK9 (Proprotein Convertase Subtilisin/Kexin 9) Enhances Platelet Activation, Thrombosis, and Myocardial Infarct Expansion by Binding to Platelet CD36. Circulation 2021, 143, 45-61. [CrossRef]

91. Zhao, S.P.; Dong, S.Z. Effect of tumor necrosis factor alpha on cholesterol efflux in adipocytes. Clin. Chim. Acta 2008, 389, 67-71. [CrossRef]

92. Ma, K.L.; Ruan, X.Z.; Powis, S.H.; Chen, Y.; Moorhead, J.F.; Varghese, Z. Inflammatory stress exacerbates lipid accumulation in hepatic cells and fatty livers of apolipoprotein E knockout mice. Hepatology 2008, 48, 770-781. [CrossRef]

93. Field, F.J.; Watt, K.; Mathur, S.N. TNF-alpha decreases ABCA1 expression and attenuates HDL cholesterol efflux in the human intestinal cell line Caco-2. J. Lipid Res. 2010, 51, 1407-1415. [CrossRef]

94. Wehmeier, K.R.; Kurban, W.; Chandrasekharan, C.; Onstead-Haas, L.; Mooradian, A.D.; Haas, M.J. Inhibition of ABCA1 Protein Expression and Cholesterol Efflux by TNF alpha in MLO-Y4 Osteocytes. Calcif. Tissue Int. 2016, 98, 586-595. [CrossRef] [PubMed]

95. Zhao, S.; Jiang, J.; Jing, Y.; Liu, W.; Yang, X.; Hou, X.; Gao, L.; Wei, L. The concentration of tumor necrosis factor-alpha determines its protective or damaging effect on liver injury by regulating Yap activity. Cell Death Dis. 2020, 11, 70. [CrossRef]

96. Gareb, B.; Otten, A.T.; Frijlink, H.W.; Dijkstra, G.; Kosterink, J.G.W. Review: Local Tumor Necrosis Factor-alpha Inhibition in Inflammatory Bowel Disease. Pharmaceutics 2020, 12, 539. [CrossRef] [PubMed]

97. Del Valle, D.M.; Kim-Schulze, S.; Hsin-Hui, H.; Beckmann, N.D.; Nirenberg, S.; Wang, B.; Lavin, Y.; Swartz, T.; Madduri, D.; Stock, A.; et al. An inflammatory cytokine signature helps predict COVID-19 severity and death. medRxiv 2020. [CrossRef]

98. Gerriets, V.; Bansal, P.; Goyal, A.; Khaddour, K. Tumor necrosis factor inhibitors. In StatPearls; StatPearls Publishing: Treasure Island, FL, USA, 2020.

99. Vasile, E.; Simionescu, M.; Simionescu, N. Visualization of the binding, endocytosis, and transcytosis of low-density lipoprotein in the arterial endothelium in situ. J. Cell Biol. 1983, 96, 1677-1689. [CrossRef]

100. Ghaffari, S.; Jang, E.; Naderinabi, F.; Sanwal, R.; Khosraviani, N.; Wang, C.; Steinberg, B.E.; Goldenberg, N.M.; Ikeda, J.; Lee, W.L. Endothelial HMGB1 Is a Critical Regulator of LDL Transcytosis via an SREBP2-SR-BI Axis. Arterioscler. Thromb. Vasc. Biol. 2021, 41, 200-216. [CrossRef]

101. Molino, Y.; David, M.; Varini, K.; Jabes, F.; Gaudin, N.; Fortoul, A.; Bakloul, K.; Masse, M.; Bernard, A.; Drobecq, L.; et al. Use of LDL receptor-targeting peptide vectors for in vitro and in vivo cargo transport across the blood-brain barrier. FASEB J. 2017, 31, 1807-1827. [CrossRef]

102. Deane, R.; Sagare, A.; Hamm, K.; Parisi, M.; Lane, S.; Finn, M.B.; Holtzman, D.M.; Zlokovic, B.V. apoE isoform-specific disruption of amyloid beta peptide clearance from mouse brain. J. Clin. Investig. 2008, 118, 4002-4013. [CrossRef]

103. Havel, R.; Eder, H.; Bragdon, J. The distribution and chemical composition of ultracentrifugally separated lipoproteins in human serum. J Clin. Investig. 1955, 34, 1345-1353. [CrossRef]

104. Skipski, V.P.; Barclay, M.; Barclay, R.K.; Fetzer, V.A.; Good, J.J.; Archibald, F.M. Lipid composition of human serum lipoproteins. Biochem. J. 1967, 104, 340-352. [CrossRef]

105. Kuchinskiene, Z.; Carlson, L.A. Composition, concentration, and size of low density lipoproteins and of subfractions of very low density lipoproteins from serum of normal men and women. J. Lipid Res. 1982, 23, 762-769. [CrossRef]

106. Mahley, R.W.; Innerarity, T.L.; Rall, S.C., Jr.; Weisgraber, K.H. Plasma lipoproteins: Apolipoprotein structure and function. J. Lipid Res. 1984, 25, 1277-1294. [CrossRef]

107. Andreae, W.A. A sensitive method for the estimation of hydrogen peroxide in biological materials. Nature 1955, 175, 859-860. [CrossRef]

108. Allain, C.C.; Poon, L.S.; Chan, C.S.; Richmond, W.; Fu, P.C. Enzymatic determination of total serum cholesterol. Clin. Chem. 1974, 20, 470-475. [CrossRef]

109. Saxena, U.; Ferguson, E.; Bisgaier, C.L. Apolipoprotein E modulates low density lipoprotein retention by lipoprotein lipase anchored to the subendothelial matrix. J. Biol. Chem. 1993, 268, 14812-14819. [CrossRef]

110. Bligh, E.G.; Dyer, W.J. A rapid method of total lipid extraction and purification. Can. J. Biochem. Physiol. 1959, 37, 911-917. [CrossRef]

111. Kaluzny, M.A.; Duncan, L.A.; Merritt, M.V.; Epps, D.E. Rapid separation of lipid classes in high yield and purity using bonded phase columns. J. Lipid Res. 1985, 26, 135-140. [CrossRef]

112. Pitas, R.E.; Innerarity, T.L.; Weinstein, J.N.; Mahley, R.W. Acetoacetylated lipoproteins used to distinguish fibroblasts from macrophages in vitro by fluorescence microscopy. Arteriosclerosis 1981, 1, 177-185. [CrossRef] [PubMed]

113. Auerbach, B.J.; Bisgaier, C.L.; Wolle, J.; Saxena, U. Oxidation of low density lipoproteins greatly enhances their association with lipoprotein lipase anchored to endothelial cell matrix. J. Biol. Chem. 1996, 271, 1329-1335. [CrossRef] [PubMed]

114. Parthasarathy, S.; Steinbrecher, U.P.; Barnett, J.; Witztum, J.L.; Steinberg, D. Essential role of phospholipase A2 activity in endothelial cell-induced modification of low density lipoprotein. Proc. Natl. Acad. Sci. USA 1985, 82, 3000-3004. [CrossRef] 
115. Burstein, M.; Scholnick, H.R.; Morfin, R. Rapid method for the isolation of lipoproteins from human serum by precipitation with polyanions. J. Lipid Res. 1970, 11, 583-595. [CrossRef]

116. McQuin, C.; Goodman, A.; Chernyshev, V.; Kamentsky, L.; Cimini, B.A.; Karhohs, K.W.; Doan, M.; Ding, L.; Rafelski, S.M.; Thirstrup, D.; et al. CellProfiler 3.0: Next-generation image processing for biology. PLoS Biol. 2018, 16, e2005970. [CrossRef] 